Portland State University

PDXScholar

$5-1-1970$

\title{
Factors in evaluation of student performance in a graduate school of social work
}

\author{
Sharon J. Copeland \\ Portland State University \\ Gerald E. Warner \\ Portland State University
}

Follow this and additional works at: https://pdxscholar.library.pdx.edu/open_access_etds

\section{Let us know how access to this document benefits you.}

\section{Recommended Citation}

Copeland, Sharon J. and Warner, Gerald E., "Factors in evaluation of student performance in a graduate school of social work" (1970). Dissertations and Theses. Paper 644.

https://doi.org/10.15760/etd.644

This Thesis is brought to you for free and open access. It has been accepted for inclusion in Dissertations and Theses by an authorized administrator of PDXScholar. Please contact us if we can make this document more accessible: pdxscholar@pdx.edu. 
FACTORS IN MHE EVALUATION OF STUDENT PERFORMANCE

IN A GRADUATE SCHOOI OF SOCIAI WORK

\author{
by \\ SHARON J. COPELAND \\ GERALI E. WARNER
}

A thesis surmitted in partiai fulfillment of the requirements for the degree of

MASTER OF

SOCIAI WORK

Portiand State University

1970 
AN ABSTRACS OF THE THESIS OF Sharon Copeland and Gerald Warner For the Masters of Social Work presented May 15, 1970.

Title: Factors in the Evaluation of Student Performance in a Graduate School of Social Work.

APFROVED BY THE MEMBERS OF THE THESIS COMMITIEE:

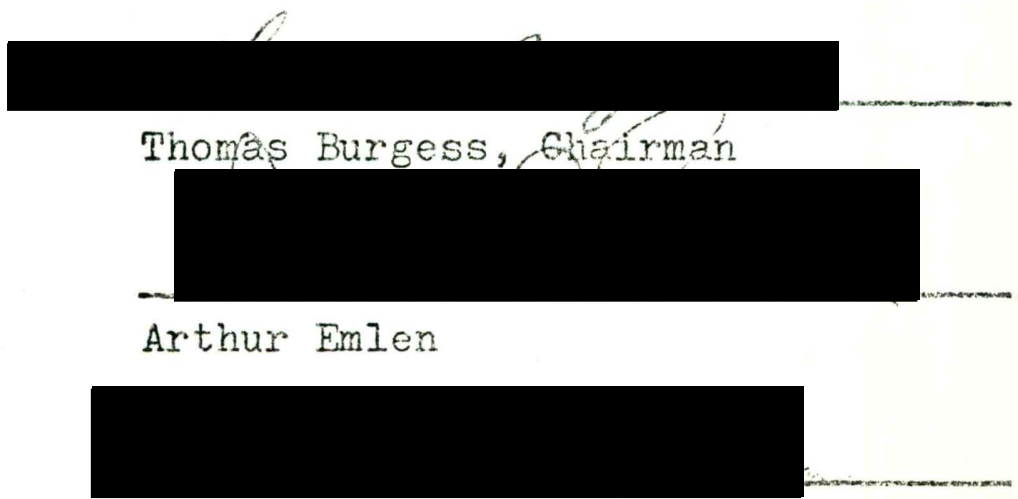

Minnie Waterman

This study refined the criteria for the measurem ment of graduate student performance in a school of social work.

By using present criteria from other studies and general student performance criteria from school brochures a questionnaire was constructed. This questionnaire was administered to a sarnole of students, faculty, and field instructors from Fortland State University School of Social Work. The data from the completed questionnaires were then processed by computer to de- 
termine the means, standard deviations of the items, and the correlations between items and between raters. Through the computed correlations, means, and standard deviations the acceptability and reliability of the questionnaire were established. Through the use of cluster analysis, clusters were formed which pointed to specific criteria by which social work students could be evaluated.

Statistical data indicated that the questionnaire was moderately acceptable and reliable. A greater acm ceptability and reliability would be desired.

The cluster analysis gave varying numbers of clusters for each group of raters. For the student raters there were seven clusters, for the first group of academic raters there were three clusters, for the second group of academic raters there were three clusters, and for the field raters there were two clusters. The ratings of both the field instructors and the second group of acadenic raters were dominated by a general.impression cluster, raising questions about the acceptability and the reliability of the questionnaire for those raters. This general-impression cluster showed that these raters did not discriminate between characm teristics of students but rated them on the basis of a general impression of the student. 
TO THE OFFICE OF GRADUATE STUDIES:

The members of the Committee approve the thesis of Sharon J. Copeland and Gerald E. Warner prescnted May 15, 1970.

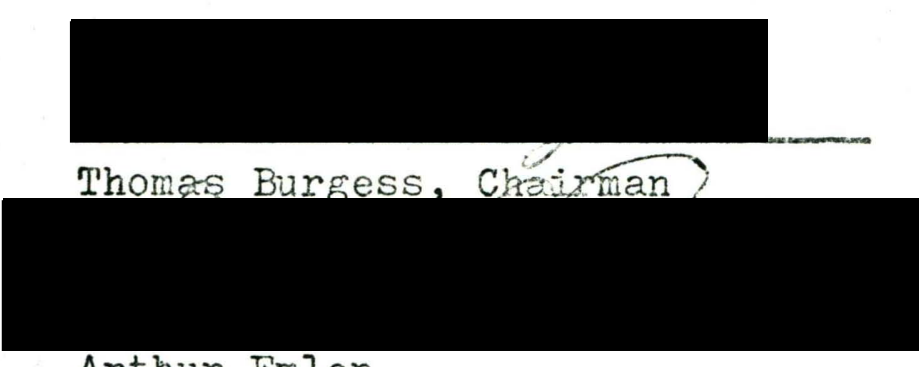

Arthur Emlen

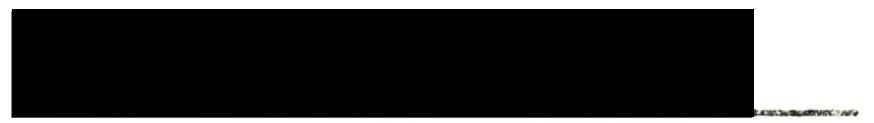

Minnie Waterman

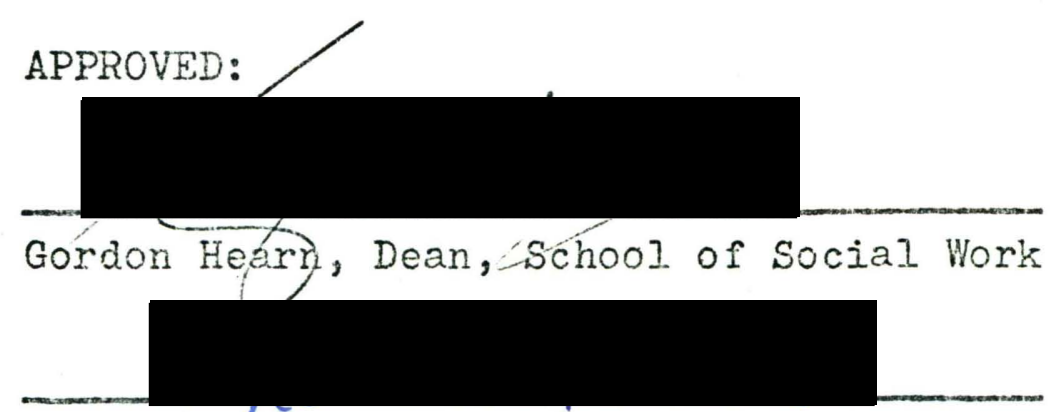

Frank I. Roberts, Acting Dean of Graduate Studies

May 15,1970 


\section{ACKNOWLEDGEMENTS}

WE WOULD LIKE TO EXPRESS OUR DEEP APPRECIATION AND INDEBTEDNESS TO THOSE WHOSE EFFORTS AND CONTRIBUTIONS MADE THIS STUDY POSSIBIE:

THOMAS BURGESS who has contributed time and patience as advisor to this project,

ARTHUR EMLEN for editing contributions,

MINNIE WATERMAN for ideas in building the basic framework for the study, and

DANIEL PURCELI for the many hours he spent in programing the study at Portland State University Computer Center.

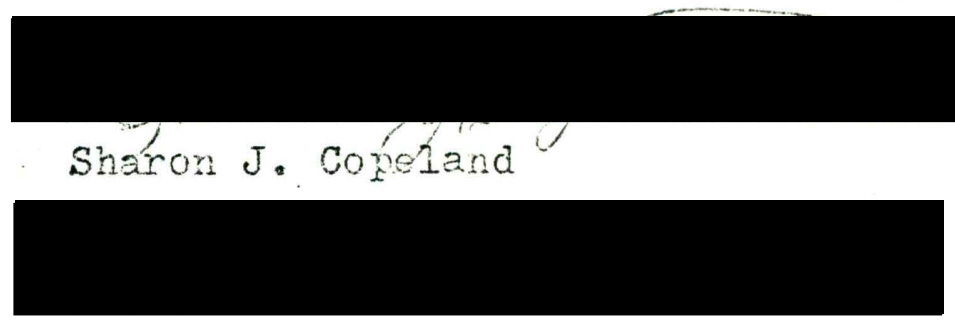

Gerald E. Warrer 
ACKNOWLEDGMENTS . . . . . . . . . .

CHAPTER

I INTRODUCTION

II METHODOLOGY . . . . . . . . . . 5

III RESULTS AND DISCUSSION • • • • • . . • • 1.

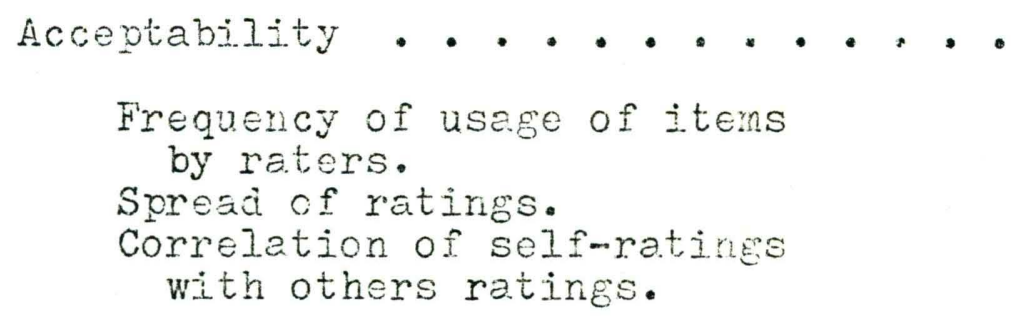

Correlations arong faculty raters.

Factors of Student Performance . . .

Self-ratings.

Academic Rater I.

Academic Rater II.

Field Instructor.

IV SUMARY AND CONCLUSTON

BIBLIOGRAPHY . . . • • • • . • • • • 


\section{LIST OF TABLES}

TABLE

PAGE

I Means And Standard Deviations Of Ratings By Type Of Rater . . . . . . . . .

II Means And Standard Deviations Of Ratings on

Students • • • • . • • • • • • •

II Correlations Between Self-Ratings And Ratings

By Faculty . . . . . . . . . .

IV Inter-rater Reliability Coefficients . . .

$V$ Intercorrelations of Items In Cluster one For

Student Self-Ratings . . . . . . .

VI Intercorrelations of Items In Cluster Two For

Student Self--Ratings . . . . . . .

VII Intercorrelations of Items In Cluster Three

For Student Self-Ratings . . . . . .

VII Intercorrelations of Items In Cluster Four

For Student Self-Ratings . . . . . .

IX Intercorrelations of Items In Cluster Fj.ve

For Student Self-Ratings . . . . .

$X$ Intercorrelations of Items In Cluster Six Fon

Student Self-Ratings ... . . . . . .

XI Intercorrelations of Items In cluster Seven

For Student Self-Ratings . . . . . .

XII Intercorrelations of Items In Cluster One For Academic Rater I • . . • . . • • • 
XIII Intercorrelations of Items In cluster Two For Academic Rater I . . . . . . . .

XIV Intercorrelations of Items In Cluster Threo For Academic Rater I . . . . . . . 34

XV Intercorrelations of Items In Cluster one For Academic Rater II . . . . . . .

XVI Intercorrelations of Items In Cluster Two For Academic Rater II . . . . . . . .

XVII Intercorrelations of Items In Cluster Three

For Academic Rater II . . . . . .

XVIII Intercorrelations of Items In Cluster one For Field Instructor Ratings . . . . . .

XIX Intercorrelations of Items In Cluster Two For

Field Instructor Ratings . . . . . 44 XX Clusters And Analyses In Which Found . . . 48 
CHAPTER I

\section{INTRODUCTION}

The process of selecting students for entrance into a graduate social work program is a major task facing the administration and faculty. Continued excellence in the profession demands that schools of social work first define the factors essential to success in the field and then establish reliable measurements of these factors.

Presently pre-entrance screening involved consideration of grade-point average and the Miller Analogies test, The validity of these criteria as predictors of success in social work has been seriously questioned. Regarding the use of the Miller Analogies test to determine the scholastic potential of school of social work applications, Burgess states in his study of Portland State College l students, "It is obvious that all of the correlations between grades and Millers scores were low. In fact, none of them were statistically significant." And he concludes,

It would appear that Miller Analogies test scores have no value in the prediction of differences in the scholastic performance of Portland State College social work students, insofar as these performances are indicated by grades.

It should also be noted that the same conclusion can be reached about the other two predictors, undergraduate G.P.A. and upper division G.P.A. The cor-

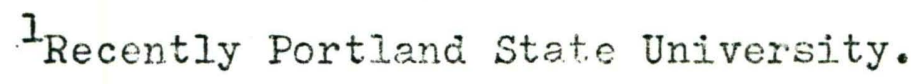


relations between these measures and social work grades were also non-significant. While Milier Ana-logies scores do not predict well for this group of students, they do as well as previous grade records do in predicting grades in social work. (I)

The limitations of the available criterion measures reflect the "inability of the profession to state clearly what knowledge, skill and values are needed for every social. worker for basic competence in practice." (2)

In professional literature devoted to the subject of student selection one finds lists of factors to be evaluated in considering school of social work applicants. In one source the following criteria are suggested: "I. intellectual skills 2. capacity for professional identity 3. capacity for change 4. capacity for critical thinking 5. capacity for establishing purposeful relationships." (3)

Guidelines for describing success in the profession can also be found in descriptions of the "ideal" social worker. Schubert characterizes the ideal caseworker as one who is "highly effective in enabling people to solve problems in soc. ial functioning," and she continues,

The following characteristics have importance insofar as they contribute to the worker's effectiveness: 1. a sense of professional identity; 2 . a command of relevant knowledge and skill; 3. an ability to face the profession's areas of ignorance, uncertainty and conflict; 4. an ability to contribute to the profession's knowledge and reduce ignorance, uncertainty and conflict. (4)

The same qualities should characterize the group worker, community organizer and administrator working with people in the problem-solving process. 
Measurements currently used in pre-entrance screening, as well as the characteristics and factors suggested in the professional literature cited above, are limited as criteria of performance in a graduate school. The former are inadequate because they do not comprehend many areas of performance relevant to success in the field; the latter, because they are too general to permit evaluation of behavior. While Schubert's characteristics provide a point of departure in establishing valid criteria, they apply to field work only and may not be applicable to other areas in the curriculum.

The first step in refining the process of student selection is the establishment of criteria 1) which include all factors relevant to successful functioning in the profession and 2) which are defined in terms of specific behavior. Having arrived at such a list of factors, the researcher must then de. sign rating scales which, when applied to the factors, will indicate the extent to which a given student evidences mastery of each skill, technique or ability.

The researchers in the present study determined the fol.. lowing objectives:

1) Hypothesize factors of performance which meet the standards of inclusiveness and specificity.

2) Determine the acceptability of these factors to students and faculty at the Portland State University School of Social Work.

3) Devise rating scales to represent these factors. 
4) Determine the acceptability of these rating scales to the same subjects as outlined in 2).

5) Determine the reliability of the rating scales.

6) Determine the basic factors within these scales. 
CHAPTER II

\section{METHODOLOGY}

A tentative set of rating scales was prepared to measure present student performance. Attributes covered by the scales were those suggested by Schubert and by the School of Social. Work catalogues. Schubert's characteristics included "I) a sense of professional identity; 2) a command of relevent know ledge and skill; 3) an ability to face the profession's area. of ignorance, uncertainty, and conflict." (4)

The School of Social Work statement included the following, based on a statement by the Council on Social Work Education.

The goals of the school are attained when the student:

Incorporates the knowledge and values basic to social work as a professional discipline.

Understands the central concepts, principles and techniques applied in social work practice and their significant variations by method and by field of practice.

Manifests compassionate respect for individuals, and appreciates man's capacity for growth and change.

Attains a level of competence necessary for responsible entry into professional practice and sufficient to serve as a basis for a creative and productive professional career.

Develops the discipline and self-awareness of the professional social worker, and accepts responsibility for the continued development of his own competence. 
Accepts an obligation to contribute responsibility to the achievement of social welfare objectives that express the goals of a democratic society and to the development of the profession that it may increasingly serve society in the prevention of social problems and the enhancement of social well-being. (5)

The characteristics as stated were considered too general to be evaluated by a rating scale, so-an attempt was made to break down the characteristics and qualities into specific behaviors which could be readily identified.

I. Student's academic skills and scholarly attitudes.

A. Ability to remember, and to apply meaningfully academic material presented.

B. Ability to be analytic in both written and oral communication.

C. Originality in oral and written communication.

D. Intelligibility of oral and written communication.

E. Neatness in, and conformity to, conventional writing standards.

F. Evidence of completing readings both assigned and others.

G. Initiative and openness in regard to the social work curriculum.

II. Student's capacity to establish purposeful relationships.

A. Frequency of reasoned disagreement with professors.

B. Constructive relationships with professors and peers. 
C. Consistency in communication with other students, instructors and supervisors.

D. Accuracy of perception of other students, instructors and supervisors.

III. Student's conmand of relevant knowledge and skill.

A. Perception of, and performance in, a formed group.

B. Accuracy of perception of important aspects of the clients' emotional life.

c. Accuracy of the understanding of relationships with his clients.

D. Abilities with client's problems and attitudes.

E. Accuracy of perception of client's social and economic needs.

F. Accuracy of perception of a family group.

IV. How the student handles responsibilities that are part of the profession.

A. How well he manages his work load.

B. Observance of agency policies.

C. Contribution to agency policy development and reorganization.

D. Awareness of the implications of social issues to social work practices.

V. Capacity for professional identity.

A. Ability to examine self.

B. Ethical standards in his work. 
C. Handling of his reaction to conflict or opposition.

D. Motivation and commitment to social work.

A sample of students, faculty and field instructors evaluated the questjonnaire to determine if it was understandable, operational and complete. Revisions were made incorporating their suggestions. The improved questionraire can be seen in appendix A.

In September, 3968, 58 students entered the School of Social Work at Portland State University. At the time the questionnaire was completed, at the end of their first year, 51 of these students were still enrolled and this group of 51 comprised the sample of students, $i . e .$, the group whose performance would be evaluated using the questionnaire. Before the questionnaire was administered it was coded by an individual. who did not know the respondents in order to maintain anonymity. For the purpose of evaluating the questionnaire it was administered to four groups: the 51 students, who were instructed to evaluate themselves (the Self-Ratings) four instructors of social work methods, each of whom was asked to evaluate the first year student enrolled in his section (referm red to as Academic Rater II); two instructors of social welfare history, each of whom was asked to evaluate the students in his section (Academic Rater I); 17 field instructors, each of whom evaluated those first-year students assigned to him for supervision of field experience (referred to as Field). As each of 
the 51 students was to be evaluated four times, once by himself, once by a social work methods instructor, once by a social welfare history instructor, and once by a field instructor, a total of 204 questionnaires was distributed. 199 of these were completed according to instructions and returned. (Four students failed to return their self-evaluations, and one field instructor did not return the questionnaire regarding a student under his supervision).?

In scoring, each response to an item on the completed. questionnaire was assigned a numerical value from 1 to 9 depending upon its location along a nine-point continuum. Minimal performance in a given area was rated $I$ and the scale continued through a rating of 9 for outstanding or exceptional performance. The numerical values of item responses were then punched on paper tape for computer processing. All statistical computations were done on a CDC 3000 at Oregon State University through a remote terminal in the Computer Center at Portland State Uni.versity.

The computer was programmed to compute the means, and standard deviations for all items as well as correlation coefficients among all items.

Acceptability of the questionnaire items was to be determined from an analysis of the student responses, i.e., how many

2 Error in punching of tape which accounts for one less Methods Rating and one more Field Rating. 
of the items elicited a response and the correlations between student self-ratings and the faculty ratings for the same items. The questionnaire would be considered acceptable if the majority of the items were answered and if a high correlation was found between self and instructor ratings.

Reliability of the questionnaire was to be determined froin the correlations between the ratings given by different faculty raters on the same student.

The factors of student performance were discovered by means of a cluster analysis in which highly correlated ratings were grouped. These clusters were interpreted and named, per.. mitting a comparison of the clusters found for each type of rater. It was hoped that similar clusters would be found in order to validate the factors and to provide a basis for simplification of future versions of the rating scales.

The cluster analysis was used to group items together which correlate highly with each other. This was done using a correlation matrix based on the questionnaire variables. The two items in the matrix showing the highest correlation formed the nucleus of the cluster. The cluster was then expanded by selecting variables in descending order of their correlation. to the nucleus variables until all which correlated highly were included.

The nucleus of a second cluster was formed of two variables with high correlations to each other and low correlations to items in the first cluster. The process was continued until all apparently significant clusters had been isolated. 
CHAPTER III

\section{RESULTS AND DISCUSSION}

\section{ACCEPTABIIITY}

\section{Frequency of Usage of Items by Raters}

As was stated in Chapter II an initial measure of the acceptability of the questionnaire would be whether the majority of the items were answerable. The data show that a majority of the questions were answered and therefore, at least from this standpoint, the questionnaire was acceptable. This is evident particularly in the responses of students and fieid instructors. The ratings given students by academic raters indicated that their knowledge of the student was too limited to respond appropriately to many questionnaire items. For example, the academic raters were unable to evaluate such areas as field work, agency policies, and management of work load.

The following chart gives the mean, standard deviation and number of responses to each item in the questionnaire as based on (left to right): student self-ratings ( 47 possible responses); academic rater one ( 51 possible responses); academic rater two (50 possible responses); field instructors ( 51 possible responses). 
TABLE I

MEANS AND STANDARD DEVIATIONS OF RATINGS BY TYPE OF RATER

\begin{tabular}{|c|c|c|c|c|c|c|c|c|c|c|c|c|}
\hline & & & & & demic & I & Acad & c & II & & & \\
\hline em & M & & $\mathrm{N}$ & M & & $\mathrm{N}$ & M & S.D. & $\mathrm{N}$ & M & S.D. & N \\
\hline$I$ & & & 47 & & & 51 & & & 50 & & & 49 \\
\hline 2 & 6.06 & 1.23 & 46 & 5.90 & 1.11 & 50 & 5.88 & 1.92 & 50 & 6.31 & 1.38 & 51 \\
\hline 3 & & & 47 & & 1.17 & 51 & & & 50 & & & 48 \\
\hline 4 & & & 47 & & & 50 & & & 49 & & & 21 \\
\hline 5 & & & 47 & & & 51 & & & 50 & 5.42 & 1.803 & 38 \\
\hline 6 & & & 47 & & & 48 & & & 50 & & & 51 \\
\hline 7 & & & 47 & & & 49 & & & 50 & & & $4 ?$ \\
\hline 8 & 6.42 & & 47 & & & 7 & & & 50 & 7.13 & 1.80 & 24 \\
\hline 9 & 6.82 & & 47 & 6.33 & 1.21 & 6 & 7.00 & 1.64 & 50 & 6.79 & 2.01 & 28 \\
\hline 10 & 6.06 & 2.03 & 47 & & 1.82 & 51 & & & 50 & 6.13 & $1.82 \mathrm{~L}$ & 46 \\
\hline 11 & 7.06 & & 47 & & & 47 & & & 50 & 7.18 & 1.74 & 51 \\
\hline 1.2 & & & 47 & & & 46 & & & 50 & 6.84 & 1.27 & 51 \\
\hline (2) & 6.04 & 0.95 & 47 & 6.39 & 0.89 & 51 & & & 49 & 6.44 & 1.57 & 50 \\
\hline 14 & & & 47 & & & $5 I$ & & & 49 & & 1.85 & 46 \\
\hline 15 & 6.67 & & 46 & 6.62 & 0.87 & 51 & 6.12 & 2.07 & 34 & 6.23 & 1.78 & 47 \\
\hline 16 & 6.69 & & 45 & & & 51 & & & 35 & & .694 & 49 \\
\hline 17 & 7.16 & & 45 & & & 45 & & & & & 1.674 & \\
\hline 18 & .6 .98 & & 4) & & & 46 & & & 36 & & 1.495 & 51 \\
\hline 19 & & & 16 & & & 29 & & & 15 & 6.76 & 7772 & \\
\hline 20 & & & 16 & 6.94 & 0.88 & 32 & 6.50 & 1.01 & 14 & 6.76 & 1.224 & \\
\hline 21 & 6.57 & 0.91 & 46 & 7.00 & 0 & 1 & 6.22 & 1.28 & 23 & 6.72 & 1.23 & 50 \\
\hline
\end{tabular}




\begin{tabular}{|c|c|c|c|c|c|c|c|c|c|c|c|}
\hline \multirow[b]{2}{*}{ Item } & \multicolumn{3}{|c|}{ Self-rating } & \multicolumn{2}{|c|}{ Acadenic } & \multirow{2}{*}{$\frac{I}{N}$} & \multicolumn{2}{|c|}{ Academic } & \multirow{2}{*}{$\frac{I I}{N}$} & \multicolumn{2}{|c|}{ Field } \\
\hline & $M$ & S.D. & $\mathrm{N}$ & $M$ & S.D. & & $M$ & S.D. & & $M$ & S.D. \\
\hline 22 & 7.09 & 1.08 & 47 & 7.69 & 1.35 & 35 & 7.2 & 2.06 & 33 & 6.7. & 1.91 \\
\hline
\end{tabular}

$\begin{array}{llllllllllllll}23 & 6.67 & 1.40 & 46 & 4.00 & 0 & 1 & 5.93 & 1.73 & 14 & 6.85 & 1.44 & 46\end{array}$ $\begin{array}{llllllllllll}24 & 6.49 & 1.08 & 45 & 0 & 0 & 0 & 7.00 & 0 & 1 & 6.541 .31 & 35\end{array}$ $\begin{array}{llllllllllll}25 & 6.87 & 1.21 .45 & 0 & 0 & 0 & 7.00 & 0 & 2 & 6.97 & 1.26 & 37\end{array}$ $\begin{array}{llllllllllll}26 & 7.47 & 0.99 & 47 & 0 & 0 & 0 & 6.54 & 1.36 & 35 & 7.18 & 1.1 .15\end{array}$

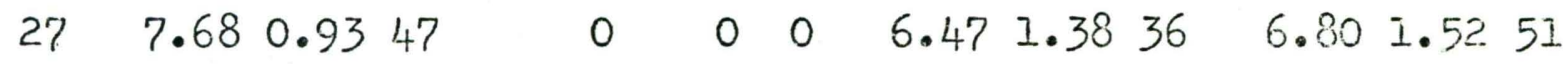

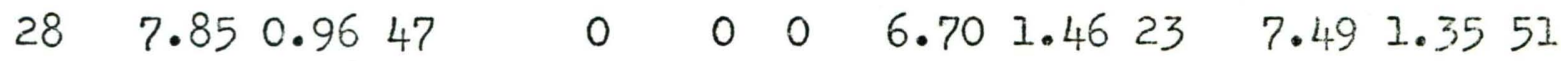
$\begin{array}{lllllllllllll}29 & 7.76 & 0.92 & 46 & 0 & 0 & 0 & 6.72 & 1.25 & 32 & 7.18 & 1.34 & 50\end{array}$ $\begin{array}{lllllllllllll}30 & 8.00 & 0.81 & 47 & 0 & 0 & 0 & 7.031 .04 & 35 & 7.51 & 1.32 & 51\end{array}$ $\begin{array}{llllllllllllllll}31 & 7.63 & 0.90 & 47 & 0 & 0 & 0 & 7.05 & 1.62 & 21 & 7.42 & 1.43 & 50\end{array}$ $\begin{array}{lllllllllllllll}32 & 7.62 & 0.77 & 47 & 0 & 0 & 0 & 6.83 & 1.85 & 12 & 7.30 & 1.73 & 50\end{array}$ $\begin{array}{lllllllllllll}33 & 7.51 & 0.88 & 47 & 0 & 0 & 0 & 6.27 & 1.91 & 15 & 7.10 & 1.30 & 51\end{array}$

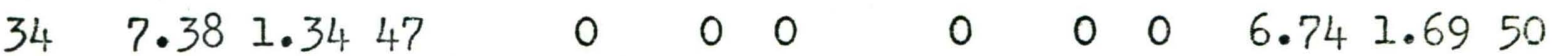
$\begin{array}{lllllllllllll}35 & 6.30 & 1.73 & 47 & 6.67 & 0.95 & 51 & 6.20 & 1.55 & 49 & 6.31 & 1.80 & 35\end{array}$

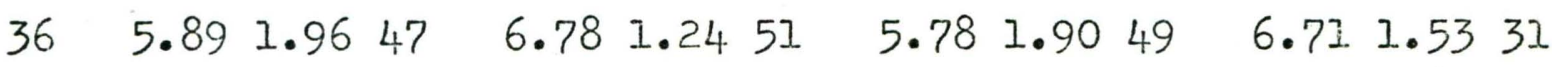

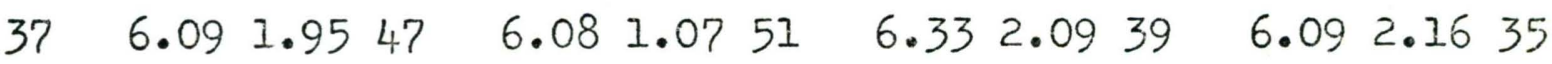
$\begin{array}{lllllllllllll}38 & 7.64 & 0.87 & 47 & 7.00 & 0 & 1 & 6.63 & 1.75 & 19 & 7.18 & 1.53 & 51\end{array}$

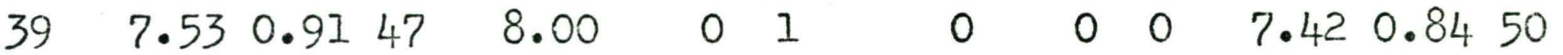
$\begin{array}{lllllllllllll}40 & 7.51 & 0.95 & 47 & 0 & 0 & 0 & 6.67 & 1.47 & 27 & 7.18 & 1.60 & 51\end{array}$

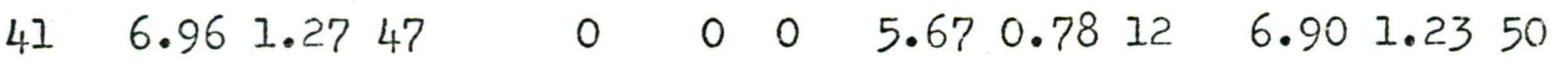
$\begin{array}{llllllllllll}42 & 6.551 .28 & 47 & 0 & 0 & 0 & 5.15 & 1.73 & 34 & 6.14 & 1.97 & 51\end{array}$ $\begin{array}{lllllllllllll}43 & 6.42 & 1.31 & 45 & 0 & 0 & 0 & 5.48 & 1.46 & 33 & 6.28 & 1.70 & 47\end{array}$ $\begin{array}{llllllllllll}44 & 6.521 .5042 & 0 & 0 & 0 & 5.00 .1 .411 & 14 & 6.681 .28 & 38\end{array}$ 


\begin{tabular}{|c|c|c|c|c|c|c|c|c|c|c|c|}
\hline & Selt & $f$-rats & ing & Acac & $d e m i c$ & & Acad & demic & $I I$ & & ielad \\
\hline Item & M & S.D. & $N$ & M & S.D. & $\mathrm{N}$ & $\mathrm{M}$ & S.D. & $\mathrm{N}$ & M & S.D. \\
\hline 45 & 6.76 & 1.65 & 42 & 0 & 0 & 0 & 4.00 & 0 & 1 & 6.60 & 1.5835 \\
\hline 46 & 7.66 & 1.09 & 47 & 6.53 & 0.81 & 51 & 6.90 & 1.52 & 48 & 7.55 & 1.1751 \\
\hline 47 & 7.22 & 1.36 & 46 & 6.67 & 0.76 & 36 & 7.35 & 1.92 & 26 & 7.25 & 1.3851 \\
\hline 48 & 7.74 & 1.13 & 47 & 7.00 & 0 & 1 & 0 & 0 & 0 & 8.20 & 0.8650 \\
\hline 49 & 6.07 & 1.81 & 46 & 8.00 & 0 & 1 & 0 & 0 & 0 & 5.68 & 1.7540 \\
\hline 50 & 8.17 & 1.11 & 47 & 8.32 & 1.02 & 50 & 7.77 & 1.46 & 39 & 7.80 & $1.335]$ \\
\hline 51 & 6.89 & 1.37 & 46 & 6.81 & 1.22 & 43 & 7.18 & 1.63 & 45 & 6.75 & 1.1044 \\
\hline
\end{tabular}

\section{Spread of Ratings}

A second indicator of the acceptability of the scales would be the extent to which raters tended to use the whole continuum of values.

Responses (see table two) indicated that the majority of the raters consistently rated students at the upper end of the scale. A number of raters used the entire continuum in evaluating students on individual items as indicated by the stand.ard deviations.

As all raters were able to use the scales provided, the rating scale was consjdered acceptable in this sense. 
TABIE II

MEANS AND STANDARD DEVIATIONS

OF RATINGS ON STUDENTS

\begin{tabular}{|c|c|c|c|c|c|c|c|c|c|c|c|c|}
\hline & Self & + & ing & Acad & demic & & Aca. & demic & II & & ield & \\
\hline $\begin{array}{l}\text { tu- } \\
\text { lent }\end{array}$ & M & S.D. & $\mathbb{N}$ & M & S.D. & $\mathrm{N}$ & M & S.D. & $\mathrm{N}$ & M & S.D. & $\mathrm{N}$ \\
\hline 34 & 6.71. & 1.23 & 45 & 6.97 & 0.95 & 28 & 7.05 & & 35 & 6.97 & 1.054 & 42 \\
\hline 35 & 6.40 & 1.73 & 49 & 5.19 & 7.07 & 21 & 4.25 & 1.88 & 32 & 3.62 & 1.845 & 51 \\
\hline 36 & 6.96 & 1.48 & 51 & 7.61 & 0.75 & 26 & 4.76 & 1.63 & 39 & 6.96 & 1.075 & 51 \\
\hline 37 & 6.98 & 1.58 & 50 & 6.73 & 0.96 & 26 & 6.14 & 1.42 & 21 & 7.33 & 1.394 & 42 \\
\hline 38 & 7.37 & 1.08 & 51 & 7.33 & 0.91 & 21 & 6.38 & 1.81 & 39 & 8.43 & 0.815 & $5 i$ \\
\hline 39 & 6.10 & 2.19 & 49 & 6.68 & 1.09 & 22 & 6.76 & 1.05 & 34 & 7.85 & 1.093 & 39 \\
\hline 40 & 7.2 .4 & 1.14 & 51 & 7.67 & 1.49 & 24 & 3.74 & 1.88 & 34 & 6.65 & 0.875 & 51 \\
\hline 41 & 7.10 & 1.40 & 51 & 5.52 & 1.16 & 25 & 3.46 & 1.53 & 24 & 6.44 & 1.395 & 50 \\
\hline 42 & 7.06 & 1.22 & 51 & 6.15 & 1.38 & 26 & 5.76 & 1.56 & 33 & 4.00 & 2.324 & 43 \\
\hline 43 & 6.27 & 1.35 & 48 & & 0.5 & 26 & & 1.42 & 37 & 5.31 & 1.265 & \\
\hline 44 & 7.22 & 1.04 & 50 & 6.41 & & 27 & 7. & 1.42 & 39 & 6.42 & 1.543 & \\
\hline 45 & 6.29 & 1.27 & 51 & 6.24 & 1.05 & 25 & $4 \cdot 49$ & 1.59 & 37 & 7.01 & 1.094 & 48 \\
\hline 46 & 6.15 & 1.36 & 51 & 6.23 & 1.21 & 26 & 6.66 & 1.00 & 32 & 5.60 & 1.364 & 45 \\
\hline 47 & 6.31 & 1.54 & 51 & 5.57 & 1.50 & 23 & 4.97 & 1.54 & 35 & 6.30 & 1.874 & 46 \\
\hline 48 & 6.94 & 1.65 & 51 & 6.39 & 1.27 & 23 & 8.33 & 0.85 & 21 & 7.76 & 1.195 & 51. \\
\hline 49 & & & & 6.72 & 1.03 & 22 & 6.24 & 1.65 & 33 & 6.80 & 1.434 & \\
\hline 50 & 7.25 & 1.71 & 51 & 6.00 & 1.02 & 66 & 6.00 & 1.48 & 31 & 7.93 & 1.064 & \\
\hline 51 & 7.57 & 1.17 & 51 & 6.60 & 1.15 & 25 & 7.29 & 0.96 & 37 & 5.58 & 2.094 & \\
\hline 52 & 6.66 & 1.11 & 51 & 6.33 & 1.11 & 21 & 5.85 & 1.33 & 39 & 7.67 & 1.354 & 46 \\
\hline 53 & 8.43 & 0.85 & 51 & 6.81 & 1.02 & 26 & 7.24 & 0.95 & 37 & 7.89 & 0.934 & \\
\hline 54 & & & & 6.73 & 1.19 & 26 & 6.38 & 0.97 & 21 & 5.34 & 1.814 & \\
\hline
\end{tabular}




\begin{tabular}{lllllllllll}
\hline & Self-rating & Academic I & Academic II & \multicolumn{2}{l}{ Field } \\
\hline $\begin{array}{l}\text { Stu- } \\
\text { dent }\end{array}$ & M S.D. $N$ & M & S.D. $N$ & M & S.D. N N & M & S.D. & $N$ \\
\hline
\end{tabular}

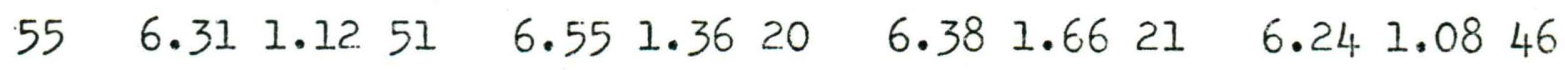

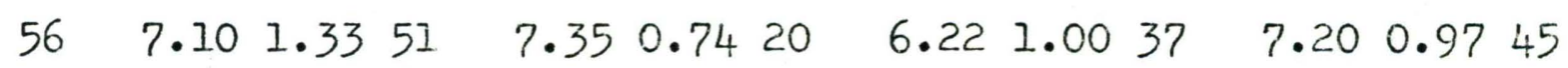
57 $\begin{array}{llllllll}6.26 & 1.4026 & 7.89 & 0.6735 & 6.84 & 1.08 & 44\end{array}$

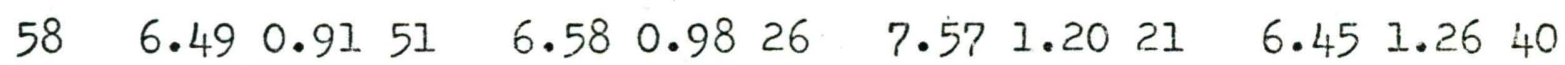

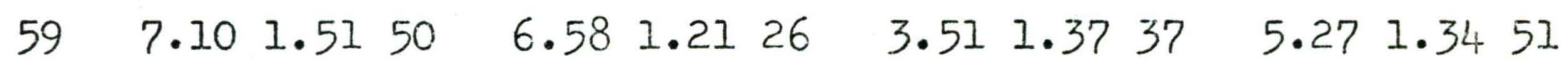

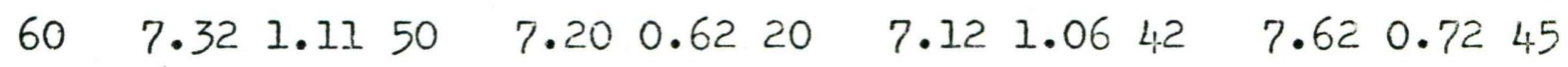

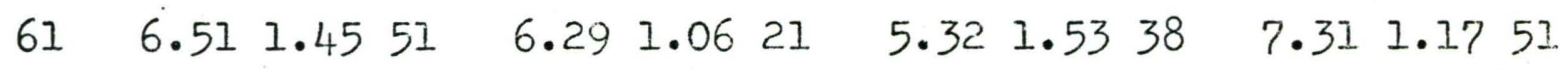

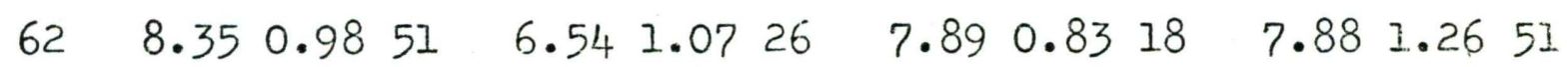

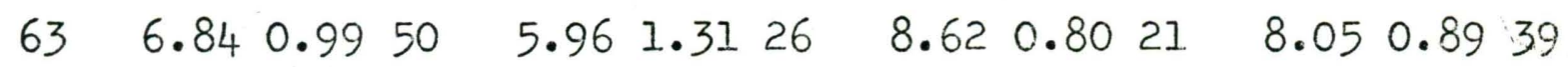

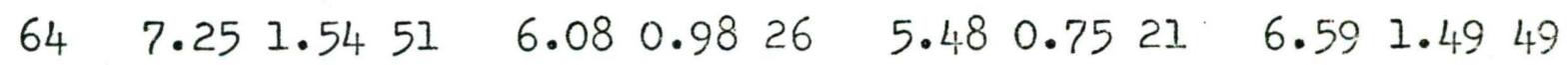

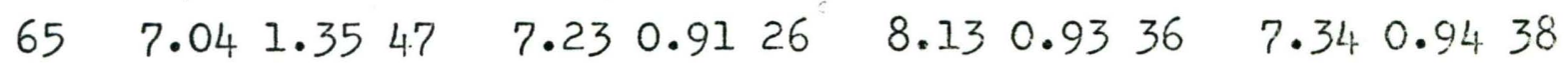

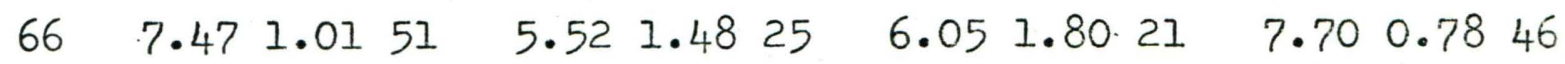
$\begin{array}{lllllllllllll}67 & 7.10 & 1.21 & 49 & 7.73 & 0.77 & 26 & 7.54 & 0.91 & 39 & 6.83 & 1.04 & 40\end{array}$

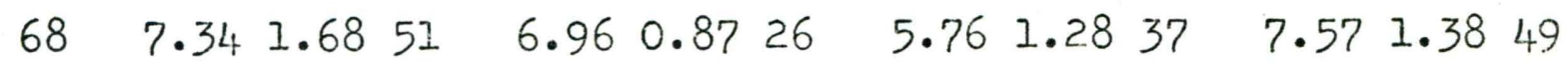
69

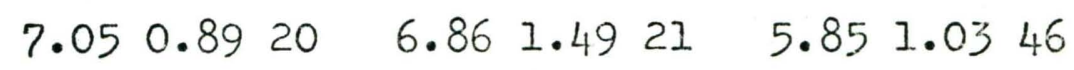
$\begin{array}{lllllllllllll}70 & 5.70 & 2.15 & 51 . & 6.43 & 1.47 & 23 & 6.28 & 1.75 & 39 & 6.51 & 1.79 & 45\end{array}$ $\begin{array}{llllllllllllll}71 & 6.29 & 1.47 & 51 & 7.77 & 0.87 & 22 & 7.76 & 1.26 & 21 & 7.40 & 0.87 & 47\end{array}$ $\begin{array}{lllllll}72 & 6.57 & 0.83 & 51 & 7.58 & 0.58 & 26\end{array}$ 7.421 .1221 $\begin{array}{llllllllllllll}73 & 6.61 & 1.74 & 49 & 7.54 & 0.63 & 28 & 7.50 & 1.02 & 34 & 7.02 & 0.92 & 51 .\end{array}$ $\begin{array}{llllllllllllll}74 & 7.12 & 1.24 & 50 & 7.68 & 0.66 & 28 & 7.21 & 0.98 & 37 & 7.04 & 0.88 & 49\end{array}$

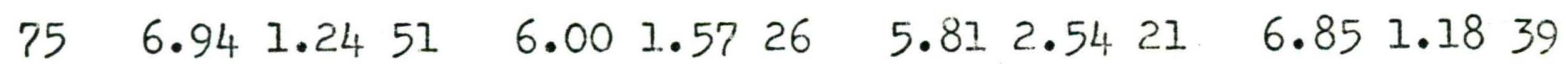

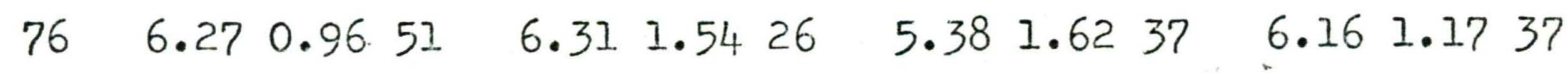




\begin{tabular}{|c|c|c|c|c|c|c|c|c|c|c|c|}
\hline & & $f$ & & Acad & c & $I$ & & $c$ & II & & \\
\hline $\begin{array}{l}\text { Eu- } \\
\text { ent }\end{array}$ & M & S.D. & N & $M$ & S.D. & $\mathrm{N}$ & $M$ & S.D. & $\mathbb{N}$ & $\mathrm{M}$ & S.D. N \\
\hline 77 & & & 51 & & & 21 & & & 37 & & 0.7251 \\
\hline 78 & 7.53 & & 5.1 & & 0.77 & 26 & 7.97 & & 30 & 8.11 & 0.8546 \\
\hline 79 & 23 & & 47 & 6.42 & & 26 & 6.11 & & 37 & 6.54 & 1.1146 \\
\hline 80 & 7.00 & 0.6 & 51 & .00 & 1.06 & 21 & 7.27 & & 33 & 7.73 & $1.30 \quad 51$ \\
\hline 81 & 7.02 & & 50 & 6.48 & & 21 & 7.87 & & 20 & 7.48 & 0.7448 \\
\hline 82 & 7.53 & & 51 & & & 18 & & & 21 & 5.56 & 1.2043 \\
\hline 83 & & 1.12 & 51 & & 0.99 & 26 & & 0.99 & 37 & 7.65 & 1.0648 \\
\hline 84 & 6.24 & 1.54 & 51 & 7.19 & 1.08 & 21 & 6.57 & 1.17 & 37 & 6.65 & 1.6446 \\
\hline
\end{tabular}

\section{Correlation of Self-Ratings with Others Ratings}

The third measurement of acceptability is how well student self-ratings correlate with those of academic and field raters. The relevant data is summarized in Table III.

Summarizing the data in Table III, correlations of student self-ratings with ratings by Academic Rater I varied from -.38 to .68 (median correlation .34); with ratings of Academic Rater II, from -.40 to .68 (median correlation .34); with ratings of Field Instructors, from -.14 to .61 (median correlation .33). These were not as high as vould be desirable. These relatively low correlations indicate that, in describing the student, the raters did not tend to rank the student's strengths and weaknesses as the student ranked them himself. 
TABLE III

CORRELATIONS BETWEEN SELF-RATINGS

AND RATINGS BY

FACUITY

\begin{tabular}{|c|c|c|c|}
\hline Student & Acad. I & Acad. II & Field \\
\hline 34 & $.53 *$ & $.63^{*}$ & $.48 *$ \\
\hline 35 & -.05 & $\cdot 38^{*}$ & $.44^{*}$ \\
\hline 36 & .01 & $.35^{*}$ & $.50 *$ \\
\hline 37 &.- .13 & $\cdot 52^{*}$ & $.59 *$ \\
\hline 38 & $.59 *$ & $.62^{*}$ & $.41 *$ \\
\hline 39 & $\cdot 51^{*}$ & $.46^{*}$ & .17 \\
\hline 40 &. .12 & .18 & .27 \\
\hline 41 & $\cdot 36$ & .05 & $\cdot 31^{*}$ \\
\hline 42 & $.67^{*}$ & .29 & .25 \\
\hline 43 & .34 & .04 & .14 \\
\hline 44 & $\cdot 55^{*}$ & $.50 *$ & $.61 *$ \\
\hline 45 & $\cdot 39$ & .24 & .19 \\
\hline 46 & $\cdot 50 *$ & $.5 I^{*}$ & .23 \\
\hline 47 & .29 & .30 & $.50 \%$ \\
\hline 48 & -.18 & .30 & $.31 *$ \\
\hline \\
\hline 50 & $.45^{*}$ & $.53 *$ & $.49 *$ \\
\hline 51 & $.56^{*}$ & $.54^{*}$ & .02 \\
\hline 52 & .19 & .22 & $.43 *$ \\
\hline 53 & -.02 & .31 & $\cdot 30^{*}$ \\
\hline
\end{tabular}

54

55

.32

$.45^{*}$

.26 


\begin{tabular}{|c|c|c|c|}
\hline Student & Acad. I & Acad. II & Field \\
\hline 56 & .31 & $.68 *$ & .04 \\
\hline \multicolumn{4}{|l|}{57} \\
\hline 58 & -.01 & $.49 *$ & $.34 *$ \\
\hline 59 & $.47^{*}$ & .12 & $.33 *$ \\
\hline 60 & $.56 *$ & .01 & $.50 *$ \\
\hline 61 & -.03 & $-.39 *$ & $.49 *$ \\
\hline 62 & .23 & .09 & .02 \\
\hline 63 & .35 & .08 & $.45 *$ \\
\hline 64 &.- .22 & .27 & $.34^{*}$ \\
\hline 65 & $.51 *$ & .30 & .22 \\
\hline 66 & -.38 & -.44 & .09 \\
\hline 67 & .28 & .30 & $.32 *$ \\
\hline 68 & .15 & -.09 & $.37^{*}$ \\
\hline \multicolumn{4}{|l|}{69} \\
\hline 70 & .34 & $.53 *$ & $.55 *$ \\
\hline 71 & .31 & .46 & $.34 *$ \\
\hline \multicolumn{4}{|l|}{72} \\
\hline 73 & .31 & $.49 *$ & .17 \\
\hline 74 & $.50 *$ & -.11 & .24 \\
\hline 75 & $.68^{*}$ & $.59 *$ & $.41 *$ \\
\hline 76 & $.40^{*}$ &.- .10 & -.14 \\
\hline 77 & .19 & $.49 *$ & $.29 *$ \\
\hline 78 & .35 & .06 & $.34^{*}$ \\
\hline 79 & .18 & .26 & .24 \\
\hline
\end{tabular}




\begin{tabular}{cccc}
\hline Student & Acad. I & Acad. II & Fieid \\
\hline 80 & -.25 & .20 & $.46^{*}$ \\
81 & .09 & $.39^{*}$ & $.55^{*}$ \\
82 & $.56^{*}$ & $.43^{*}$ & .22 \\
83 & $.53^{*}$ & .24 & $.41^{*}$ \\
84 & $.54^{*}$ & .21 & .12 \\
\hline
\end{tabular}

* Correlations significant at the .05 Jevel

\section{RELIABILITY}

\section{Correlations among Faculty Raters}

Reliability of the questionnaire was determined by com-paring the ratings given the student by each group of faculty raters.

Sumarizing the data given in Table IV, correlations between ratings given by Raters I and II range from -.34 to .76 (median correlations .33); between those by Raters I and Field range from -.30 to .60 (median correlation .30); between those by Raters II and Field range from -.30 to .59 (median correlation .29).

The data in Table IV shows some significance between the ratings of different faculty raters. Using this standard of reliability, therefore, the questionnaire must be considered reliable. The low correlations indicate that, in describing the student, two individual raters will rank student's strengths and weaknesses somewhat the same. 
TABLE IV

INTER-RATER RELIABILITY

COEFFICIENTS

\begin{tabular}{|c|c|c|c|}
\hline $\begin{array}{l}\text { Student } \\
\text { No. }\end{array}$ & $\begin{array}{l}\text { Acad. } \\
\text { I and II }\end{array}$ & $\begin{array}{l}\text { Acad. I } \\
\text { and Field }\end{array}$ & $\begin{array}{l}\text { Acad. II } \\
\text { and Field }\end{array}$ \\
\hline 34 & $.56 *$ & $.44^{*}$ & $.36^{*}$ \\
\hline 35 & .37 &. .13 & $.53^{*}$ \\
\hline 36 & & .36 & .06 \\
\hline 37 & .34 & .13 & $.44^{*}$ \\
\hline 38 & $.60 *$ & $.44 *$ & $.40 *$ \\
\hline 39 & .42 & $\cdot 52 *$ & .35 \\
\hline 40 & .18 & .28 & .12 \\
\hline 41 & -.34 & .05 & .22 \\
\hline 42 & $.42 *$ & $.43^{*}$ & $.55^{*}$ \\
\hline 43 & $.4 .7 *$ & .32 & .03 \\
\hline 44 & .29 & $.60 *$ & $.59^{*}$ \\
\hline 45 & $.39 *$ & $.43 *$ & .10 \\
\hline 46 & $.76 *$ & $.42 *$ & $.44^{*}$ \\
\hline 47 & $.48 *$ & .14 & .25 \\
\hline 48 & .12 & .14 & .28 \\
\hline \multicolumn{4}{|l|}{49} \\
\hline 50 & -.04 & .17 & $.36^{*}$ \\
\hline 51 & $.45 *$ & -.28 & -.09 \\
\hline 52 & .22 & .07 & $.59 *$ \\
\hline 53 & .02 & $.57^{*}$ & .16 \\
\hline \multicolumn{4}{|l|}{54} \\
\hline 55 & .39 & .21 & .25 \\
\hline
\end{tabular}




\begin{tabular}{|c|c|c|c|}
\hline $\begin{array}{l}\text { Student } \\
\text { No. }\end{array}$ & I Acad. & $\begin{array}{l}\text { Acad. I } \\
\text { and Field }\end{array}$ & $\begin{array}{l}\text { Acad. II } \\
\text { and Field }\end{array}$ \\
\hline 56 & $.6 I^{*}$ & -.08 & -.02 \\
\hline \multicolumn{4}{|l|}{57} \\
\hline 58 & .04 & .33 & -.26 \\
\hline 59 & .27 & $.57^{*}$ & $.52 *$ \\
\hline 60 & .31 & $.55^{*}$ & .06 \\
\hline 61 & .22 & .05 & -.03 \\
\hline 62 & .35 & -.04 & .02 \\
\hline 63 & -.03 & .41 & -.21 \\
\hline 64 & .16 & $.47^{*}$ & $.57^{*}$ \\
\hline 65 & .25 & .09 & .29 \\
\hline 66 & .12 & .31 & .32 \\
\hline 67 & .33 & .35 & .00 \\
\hline 68 & .34 & -.04 & .10 \\
\hline \multicolumn{4}{|l|}{69} \\
\hline 70 & $.48 *$ & .38 & $.53 *$ \\
\hline 71 & $.46 *$ & .03 & .10 \\
\hline \multicolumn{4}{|l|}{72} \\
\hline 73 & .19 & .28 & $.4 I^{*}$ \\
\hline 74 & .2 .2 & .31 & .13 \\
\hline 75 & .42 & .26 & -.08 \\
\hline 76 & .15 & .19 & $.56 *$ \\
\hline 77 & $.65^{*}$ & .39 & $\cdot 38 *$ \\
\hline 78 & .03 & .29 & -.30 \\
\hline
\end{tabular}




\begin{tabular}{lccc}
\hline $\begin{array}{c}\text { Student } \\
\text { No. }\end{array}$ & $\begin{array}{c}\text { Acad. } \\
\text { and II }\end{array}$ & $\begin{array}{c}\text { Acad. I } \\
\text { and FieId }\end{array}$ & $\begin{array}{c}\text { Acad. II } \\
\text { and FieId }\end{array}$ \\
\hline 79 & $.47^{*}$ & .37 & $.48^{*}$ \\
80 & .19 & -.30 & .18 \\
81 & .13 & .21 & .10 \\
82 & $.56^{*}$ & .22 & .04 \\
83 & .21 & .26 & .11 \\
84 & .39 & .30 & -.18 \\
\hline
\end{tabular}

* Correlations significant at the .05 level

FACTORS OF STUDENT PERFORMANCE

Cluster analysis was used to group the items in a manner showing their relationship with each other. Each group of items contains variables that correlate highly with one another and have low correlations with variables in other groups. This group then forms what is called a cluster. This will be reported first for clusters based on self-ratings. Items which fail to correlate with any others will be listed as "residuals".

\section{Clusters Based on Self-ratings}

Beginning with the set of student self-ratings the following clusters were found. 
TABLE V

INTERCORRELATIONS OF ITEMS IN CLUSTER ONE FOR STUDENT SEIF-RATINGS

\begin{tabular}{|c|c|c|c|c|c|c|c|}
\hline $\begin{array}{c}\text { Items } \\
8 \\
\end{array}$ & 10 & 2 & 34 & 3 & 7 & 1 & 5 \\
\hline 8100 & & & & & & & \\
\hline 1073 & .100 & & & & & & \\
\hline 960 & 57 & 100 & & & & & \\
\hline 3435 & 54 & 32 & 100 & & & & \\
\hline 348 & 53 & 51 & 25 & 100 & & & \\
\hline 743 & 46 & 61 & 20 & 53 & 100 & & \\
\hline 145 & 37 & 25 & 38 & 50 & 37 & 100 & \\
\hline $5 \quad 32$ & 40 & 41 & 30 & 71 & 42 & 59 & 10 \\
\hline
\end{tabular}

The items which were contained in the first cluster of the student self-ratings were the following:

1. Student's ability to remember and apply meaningfully acadenic material presented.

3. Ability to be analytic in mitten communication.

5. Shows originality in written communication.

8. Conformity to conventions regarding organization, citation and footnotes of written material.

9. Neatness of manuscripts. (typographical errors, strikeovers, submission of original copy, etc.

10. Conformity to conventions regarding spelling, grammar, word usage, etc.

34. Student's management of work load. 
Description: The items in cluster one reflect the ability of the student to meet standards for written work in both academic and agency settings.

\section{TABIE VI}

INTERCORRELATIONS OF ITEMS IN CLUSTER TWO

FOR STUDENT SELF-RATINGS

\begin{tabular}{llllll}
\hline Items & 29 & 31 & 42 & 47 & 43 \\
\hline 29 & 100 & & & & \\
31 & 59 & 100 & & & \\
42 & 48 & 58 & 100 & & \\
47 & 46 & 42 & 51 & 100 & \\
43 & 36 & 43 & 54 & 30 & 100 \\
\hline
\end{tabular}

The items which were contained in the second cluster of the student self-ratings were the following:

29. Student's ability to recognize client's strengths as well as weaknesses in the problem solving prom cess.

31. Professional purposefulness in contacts with clients.

42. Accuracy of student's perception about the dient's feelings.

43. Accuracy of student's perception of family group interaction.

47. Student's ethical standards in his work. 
Description: The items contained in the second cluster pertain to the student's perceptiveness in clinical vork. This involves the student's perception and ethical commitment to the client.

TABIE VII

INTERCORRELATIONS OF ITEMS IN CLUSTER THREE FOR STUDENT SELF-RATINGS

\begin{tabular}{rrrr}
\hline Iters & 35 & 36 & 32 \\
\hline 35 & 100 & & \\
36 & 66 & 100 \\
37 & 60 & 52 & 100 \\
\hline
\end{tabular}

The items which were contained in the third cluster. of the student self-ratings were the following:

35. Evidence student gives of completing assigned reading.

36. Evidence student gives of completing recommended reading.

37. Evidence student gives of doing un-mentioned reading.

Description: The items contained in the third cluster reflect the student's ability to articulate information obtained through reading. 
PABIE VIII

INTFRCORRELAPIONS OF ITEMS IN CLUSTER FOUR

FOR STUDENT SELF-RATINGS

\begin{tabular}{lllllll}
\hline Items & 44 & 45 & 51 & 23 & 25 & 24 \\
\hline 44 & 100 & & & & & \\
45 & 66 & 100 & & & \\
51 & 51 & 30 & 100 & & & \\
23 & 48 & 49 & 40 & 100 & \\
25 & 44 & 29 & 49 & 60 & 100 \\
24 & 40 & 40 & 29 & 55 & 51 & 100 \\
\hline
\end{tabular}

The items which were contained in the fourth cluster of the student self-ratings were the following:

44. Student's ability to focus group on task goals.

45. Student's ability to maintain a group while encouraging the group to develop its own unique characteristics.

51. Nature of student's reaction to opposition or conflict.

23. Accuracy of student's perception of interaction in a formed group when a participant.

25. Accuracy of student's perception of interaction in a formed group when a leader.

24. Accuracy of student's perception of interaction in a formed group when an observer. 
Description: The items in cluster four pertain to student's mastery of group techniques. This involves the ability of the student to perceive and to skillfully participate in the group process.

TABIE IX

INTERCORRELATIONS OF ITEMS IN CIUSTER FIVE FOR STUDENT SELF-RATINGS

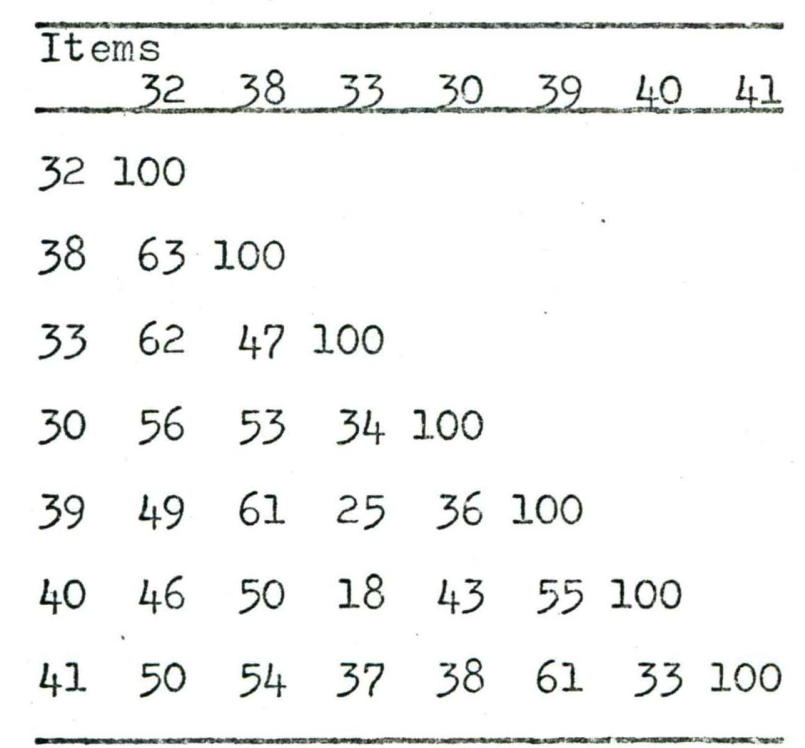

The items which were contained in the fifth cluster of the student self-ratings were the following:

32. Student's overall performance in service to clients.

38. Student's ability to handle clients feelings about a problem.

33. Estimate of student's helpfulness to clients.

30. Student's attitude toward his clients.

39. Student's ability to inform clients of resources, from other social agencies. 
40. Accuracy of student!s perception of clients' social needs.

41. Accuracy of student's perception of clients' economic needs.

Description: The items in cluster five reflect the student's effectiveness in helping clients.

TABIE X

INTERCORRELATIONS OF ITEMS IN CLUSTER SIX

FOR STUDENT SELF- RATINGS

\begin{tabular}{llll}
\hline Items & & \\
\hline 19 & 20 & 21 \\
\hline 19 & 100 & & \\
20 & 59 & 100 & \\
21 & $50 \quad 47$ & 100 \\
\hline
\end{tabular}

The items which were contained in the sixth cluster of the student self-ratings were the following:

19. Accuracy of student's perception of other students.

20. Accuracy of student's perception of instructors and supervisors.

21. Accuracy of student's perception of clients.

Description: The iters in cluster six pertain to the accuracy of the student's perception of others. 
TABLE XI

INTERCORRELATIONS OF ITEMS IN CLUSTER SEVEN FOR STUDENT SEIF-RATINGS

\begin{tabular}{lllllll}
\hline Iterns & 4 & 16 & 2 & 17 & 6 & 28 \\
\hline 4 & 100 & & & & & \\
16 & 29 & 100 & & & & \\
2 & 52 & 28 & 100 & & & \\
17 & 30 & 51 & 45 & 100 & & \\
6 & 32 & 46 & 49 & 46 & 100 \\
28 & 39 & 38 & 31 & 20 & 29 & 100 \\
\hline
\end{tabular}

The items which were contained in the seventh cluster of the student self-ratings were the following:

4. Shows originality in oral communication.

16. Constructive relationships with instructors.

2. Ability to be analytic in oral communication.

17. Constructive relationships with peers.

6. Intelizibility of oral communication.

28. Student's ability at engaging client's participation.

Description: The items in cluster seven pertain to verbal proficiency. This involves formal and informal articulation of one's ideas to instructors, peers, and clients.

Residuals: Residuals are the items which did not correlate with any other items.

11. Eagerness for suggestions. 
12. Use of suggestions.

13. Frequency of student's demands for consultation or explicit detailed assignnents.

14. Frequency of reasoned disagreement with professor.

15. Acceptance of relevant portions of the curriculum.

18. Consistency in communication with others.

22. Ability to examine self.

26. Accuracy of student's perception of significance of client's past life experiences as related to present functioning.

27. Accuracy of student's understanding of the relam tionship with clients.

46. Student's motivation in and commitment to social work.

48. Student's observance of agency policy.

49. Student's contributions to agency policy development and reorganization.

50. Student's awareness of the implications of social issues to social work practice.

Ratings by Academic Rater I

TABIE XII

INTERCORRELATIONS OF ITEMS IN CLUSTER ONE FOR ACADEMIC RATER ONE

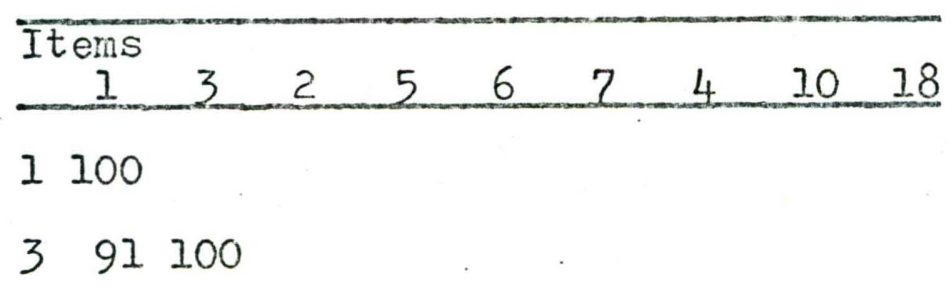




\begin{tabular}{llllllllll}
\hline Items & 1 & 3 & 2 & 5 & 6 & 2 & 4 & 10 & 18 \\
\hline 2 & 77 & 74 & 100 & & & & & & \\
5 & 75 & 78 & 78 & 100 & & & & & \\
6 & 75 & 72 & 84 & 66 & 100 & & & \\
7 & 75 & 67 & 63 & 63 & 58 & 100 & & & \\
4 & 60 & 60 & 81 & 81 & 71 & 41 & 100 & & \\
10 & 70 & 65 & 54 & 52 & 52 & 85 & 32 & 100 & \\
18 & 56 & 51 & 50 & 57 & 69 & 41 & 56 & 31 & 100
\end{tabular}

The items which were contained in the first cluster of the academic rater one are the following:

1. Student's ability to remember and apply academic material presented.

3. Ability to be analytic in written communication.

2. Ability to be analytic in oral communication.

5. Shows originality in written communication.

6. Intelligibility of oral communication.

7. Intelligibility of written communication.

4. Shows originality in oral communication.

10. Conformity to conventions regarding spelline, grammar, word usage, etc.

18. Consistency in communication with others.

Description: The items in cluster one pertain to written and verbal proficiency in meeting academic and agency requirements. 
TABIT XIII

INTERCORRELATIONS OF TTEMS IN CLUSTTER TWO FOR ACADEMIC RATER ONE

\begin{tabular}{lllllllllll}
\hline Items & 16 & 20 & 19 & 51 & 18 & 17 & 4 & 15 & 46 & 12 \\
\hline 16 & 100 & & & & & & & & \\
20 & 68 & 100 & & & & & & & \\
19 & 57 & 73 & 100 & & & & & & \\
51 & 43 & 64 & 70 & 100 & & & & & \\
18 & 53 & 66 & 81 & 54 & 100 & & & & \\
17 & 68 & 55 & 65 & 54 & 61 & 100 & & & \\
4 & 54 & 41 & 39 & 19 & 56 & 58 & 100 & & \\
15 & 56 & 58 & 61 & 19 & 41 & 20 & 55 & 100 & \\
46 & 53 & 55 & 42 & 34 & 40 & 26 & 39 & 63 & 100 \\
12 & 41 & 56 & 50 & 35 & 42 & 17 & 21 & 51 & 48 & 100 \\
\hline
\end{tabular}

The items which were contained in the second cluster for academic rater one are the following:

16. Constructive relationship with instructors.

20. Accuracy of student's perception of instructors, and supervisors.

19. Accuracy of student's perception of other students.

51. Nature of student's reaction to opposition or conflict.

18. Consistency in communication with others.

17. Constructive relationship with peers. 
4. Shows originality in oral communication.

15. Acceptance of relevant portions of the curricuIum.

46. Student's motivation in and commitment to social work.

12. Use of suggestions.

Description: The items in cluster two reflect the student's ability to adjust to the schools' standards for professional involvement. This includes accuracy of perception of people, and consistency and motivation in relationship.

TABLE XIV

INTERCORRELATIONS OF ITEMS IN CLUSTER THREE FOR ACADEMIC RATER ONE

\begin{tabular}{lllllll}
\hline \multicolumn{1}{c}{ Items } & 36 & 35 & 37 & 11 & 50 & 46 \\
\hline 36 & 100 & & & & & \\
35 & 64 & 100 & & & & \\
37 & 43 & 59 & 100 & & & \\
11 & 50 & 69 & 39 & 100 & & \\
50 & 46 & 53 & 48 & 54 & 100 \\
46 & 46 & 51 & 55 & .42 & 53 & 100 \\
\hline
\end{tabular}

The items which were contained in the third cluster of academic rater one are the following:

36. Evidence student gives of completing recommended reading. 
35. Evidence student gives of completing assigned. reading.

37. Evidence student gives of doing un-mentioned reading.

11. Eagerness for suggestions.

50. Student's awareness of the implications of social issues to social work practice.

46. Student's motivation in and commitment to social work.

Description: The items in cluster three pertain to a student's scholarly motivation and his dedication to the role of the student.

\section{Residuals:}

13. Frequency of student's demands for consultation or explicit detailed assignments.

14. Frequency of reasoned disagreement with professor. 22. Student's ability to examine self.

\section{Ratings by Academic Rater II}

The first cluster in the ratings by academic Rater II was so large that the itens, their median correlation, and their range of correlations are in the following table. The table was too large to be presented in the same form as the previous clusters. 
TABLE XV

INTERCORRETATIONS OF ITEMS IN CLUSTER I

FOR ACADEMIC RATER II

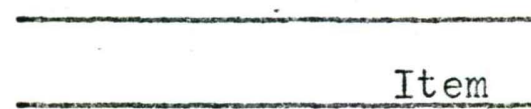

47. Student's ethical standards in his work.

21. Accuracy of student's perception of clients.

31. Professional purposefulness in contacts with clients.

79

41 to 100

32. Student's overall performance in service to clients.

26. Accuracy of student's perception of significance of clients past life experiences as related to present functioning.

33. Estimate of student's helpiulness to clients.

75

75

50 to 100

27. Accuracy of student's understanding of relationship with client. 75 51 to 95

23. Accuracy of student's perception in a formed group when a participant.

74

4]. to 87

42. Accuracy of student's perception about the client's feelings.

85

49 to 92

35 to 91

59 to 94

49 to 89

46 to 100

28. Student's ability at engaging client's participation.

41. to 87

74

41 to 92 
38. Student's ability to handle

client's feelings about a

problem.

72

51 to 100

20. Accuracy of student's per.. ception of instructors and supervisors.

72

35 to 100

19. Accuracy of student's perception of other students.

6. Intelligibility of oral communication.

1. Student's ability to remember and apply meaningfully a.cademic material presented.

29. Student's ability to recoga nize client's strengths as well as weaknesses in the problem-solving process.

2. Ability to be analytic in oral communication.

71 38 to 84

4. Shows originality in oral communication.

18. Consistency in communication with others.

43. Accuracy of student's perception of family group interaction.

50. Student's awareness of the im plications of social issues to social work practice. 


\section{Item}

30. Student's attitude toward his

clients.
Median

Correlation

68

43 to 89

3. Ability to be analytic in oral conmunication.

40. Accuracy of student's perception of client's social needs.

5. Shows originality in written communication.

7. Intelligibility of written communication.

16. Constructive relationships with peers.

44. Student's ability to focus group on task goals.

22. Ability to examine self.

15. Acceptance of relevant portions of the curriculum.

51. Nature of student's reaction to opposition or conflict.

17. Constructive relationships with peers.
68

41 to 82

65

42 to 87

62

33 to 86

62

37 to 82

59

31 to 88

59

42 to 84

58

35 to 90

55

31 to 76

48

33 to 79

Description: In the first cluster there appears to be no discrimination between items. Since there appears to be no discrimination, the cluster was too all-inclusive to be described. 
TABLE XVI

INTERCORREIATIONS OF ITEMS IN CLUSTER II FOR ACADEMIC RATER II

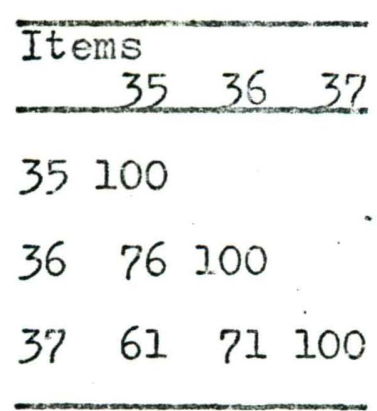

The items which were contained in the second cluster of the second academic rater are the following:

35. Evidence student gives of completing assigned reading.

36. Evidence student gives of completing recommended reading.

37. Evidence student gives of doing unmentioned readings.

Description: The items in cluster two pertain to the material the student has read which involves his retention and feedback of this material.

TABIE XVII

INTERCORRELATIONS OF ITEMS IN CIUSTER III FOR ACADEMIC RATER II

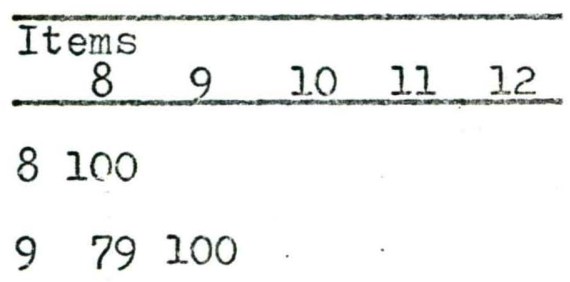




\begin{tabular}{cccccc}
\hline Items & & & & & \\
& 8 & 9 & 10 & 11 & 12 \\
\hline 10 & 76 & 79 & 100 & & \\
11 & 54 & 47 & 57 & 100 & \\
12 & 50 & 55 & 54 & 79 & 100 \\
\hline
\end{tabular}

The items which were contained in the third cluster of academic rater II are the following:

8. Conformity to conventions regarding organization, citations and footnotes or wcitten material.

9. Neatness of manuscripts. (typographical errors, strikeovers, submission of original copy).

10. Conformity to conventions regarding speling, grammar, word usage, etc.

11. Eagerness for sliggestions.

12. Use of suggestions.

Description: The items in cluster three relate to the student's acceptance of standards expected in written work. This acceptance is reflected in his conformity to witten requirements.

\section{Residuals:}

13. Frequency of student's demands for consultation or explicit detailed assignments.

14. Frequency of reasoned disagreement with professor.

41. Accuracy of student's perception of client's economic needs.

46. Student's motivation in and commitment to social work. 
TABLE XVIII

INTERCORRELATIONS OF ITEMS IN CLUSTER I. FOR FJEID INSTRUCTOR RATINGS

\section{Item}

32. Student's overall performance in service to client's.

40. Accuracy of student's perception of client's social needs.

42. Accuracy of student's perception about the client's feelings.

33. Estimate of student's helpfulness to clients.

45 to 82

20. Accuracy of student's perception of instructors and supervisors.

47 to 78

21. Accuracy of student's perception of clients.

41 to 83

43. Accuracy of student's percepm tion of family group interaction.

66 45 to 85

3. Ability to be analytic in written communication. 38 to 78

2. Ability to be analytic in oral communication.

27. Accuracy of student's understanding of relationship with client. Correlation

54 to 84

51 to 85

correlat

70

5

Range of 
23. Accuracy of student's percep-

tion of interaction of a formed group when a participant.

64

37 to 85

26. Accuracy of student's perception of the significance of client's past life experiences as related to present functioning.

64 34 to 82

29. Student's ability to recognize client's strengths as well as weaknesses in the problem solving process.

38. Student's ability to handle client's feelings about a problem.

$63 \quad 39$ to 83

6. Intelligibility of oral communication.

62

47 to 79

16. Constructive relationships with instructors.

25. Accuracy of student's perception of interaction in a formed group when a leader

62 28 to 88

51. Nature of student's reaction to opposition or conflict.

12. Use of suggestions.

61

42 to 79

18. Consistency in communication with others. 
Iteri!

24. Accuracy of student's percep-

tion of interaction in a formed

group when an observer.

30. Student's attitude towards his

clients.

60

59

39 to 73

41. Accuracy of student's perception of cljeit's economic needs.

59

34 to 69

5. Shows originality in written communication.

58

37 to 79

28. Student's ability at engaging client's participation.

57

30 to 84

50. Student's awareness of the implications of social issues to social work liractice.

39 to 74

19. Accuracy of student's perception of other students.

57

33 to 76

7. Intelligibility of written communicatior.

55

31 to 76

44. Student's ability to focus group on task goals.

54

22 to 71

45. Student's ability to maintain a group while encouraging the group to develop its own unique characteristics.

52

20 to $6 ?$

11. Eagerness for suggestions.
$52 \quad 34$ to 6 ? 


\begin{tabular}{llc}
\hline \multicolumn{1}{c}{ Item } & $\begin{array}{c}\text { Median } \\
\text { Correlation }\end{array}$ & $\begin{array}{c}\text { Range of } \\
\text { Correlation }\end{array}$ \\
\hline $\begin{array}{l}\text { Ioad. } \\
\text { 49. Student's contribution to } \\
\text { agency development and rem } \\
\text { organization. }\end{array}$ & 50 & 34 to 67 \\
$\begin{array}{l}\text { Shows originality in oral com- } \\
\text { munication. }\end{array}$ & 49 & 28 to 63 \\
\hline
\end{tabular}

Description: In the first cluster there appears to be no dism crimination between items. Since there was no discrimination, the size of the cluster was so massive that it cannot be described.

TABIE XIX

INTERCORREIATION OF ITEMS IN CLUSTER TWO

FOR FIEID INSTRUCTOR RATINGS

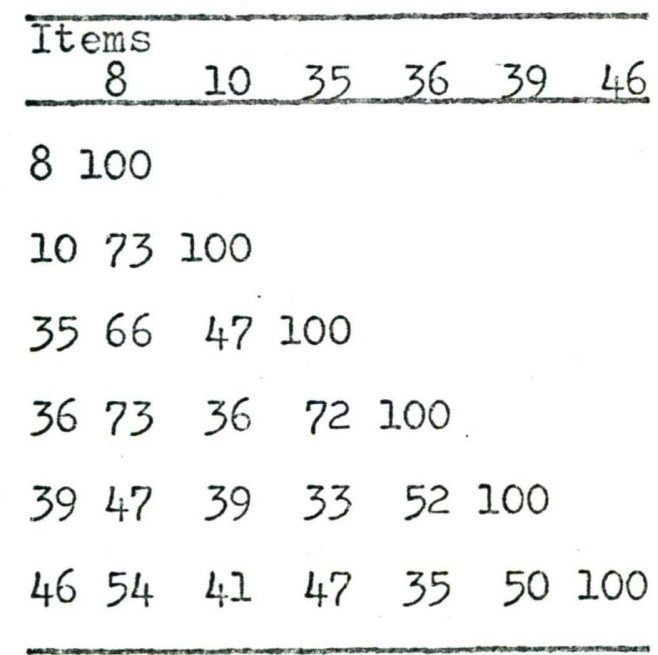


The items which vere contained in the second cluster for Field Instructor Ratings are the following.

8. Conformity to conventions regarding organization, citations, and footnotes of written material.

10. Conformity to conventions regarding spelling, grammar, word usage, etc.

35. Evidence student gives of completing assigned reading.

36. Evidence student gives of completing recommended reading.

39. Student's ability to inform clients of resources from other social agencies.

46. Student's motivation in and commitment to social work.

Description: The items in cluster two pertain to a student's motivational commitment to social work as reflected in completion of agency and school tasks.

\section{Residuals:}

9. Neatness of manuscripts. (typographical errors, strikeovers, submission of original copy•)

13. Frequency of student's demands for consultation or explicit detailed assignments.

14. Frequency of reasoned disagreement with professor.

17. Constructive relationships with peers.

22. Ability to examine self. 
37. Evidence student gives of doing un-mentioned reading.

47. Student's ethical standards in his work.

48. Student's observance of agency policy. 


\section{CHAPTER IV}

\section{SUMMARY AND CONCLUSIONS}

In this study we have attempted to refine criterion measures of student performance in a graduate socjal work program. This was done by selecting criteria from research described in professional literature and of the admission brochures from Portland State University, School of Social Work. A studentevaluation questionnaire was the tool developed to refine these criteria. The acceptability and reliability were evaluated using computed correlations, and a substantive analysis of student ratings was conducted using cluster analysis.

\section{ACCEPTABILITY}

\section{Frequency of Responses}

Frequency of response to items was one criterion of acceptability. Since the majority of items elicited a response, the questionnaire can be considered to have met this criterion.

\section{Spread of Ratings}

A second indicator of acceptability was the spread of ratings along the entire continuum of the rating scale. Although most of the raters selected responses from the upper end of the scale, some raters made use of the entire scale. In this sense the scale would seem to have provided an adequate (i. e. acceptable) rating tool. 
Self-Ratings And Other Ratings

How well student self-ratings correlated with the ratings given by academic and field raters was the third measure of acceptability. As there were many significant correlations between these ratings the questionnaire again can be considered acceptable, although the frequent low correlations suggest prow blems with student reactions to the results of ratings.

\section{RELIABILTTY}

\section{Correlations By Ratings of Others}

The reliability of the questionnaire was determined by comparing the ratings given by each group of faculty raters. In comparing the responses of faculty raters many significant correlations were found thus establishing the reliability, although the general level of the correlations were low and would suggest a need for improvement.

\section{CLUSTERS}

Table XX gives the clusters that were found and the analyses in which they were found.

TABLE XX

CLUSTER AND ANALYSIS IN WHICH FOUND

\section{Cluster}

Self

Acad.I

Acad. II

Field

1. Writing standards for

Academic and Agency

Settings.

$\mathrm{X}$

$\mathrm{X}$ 


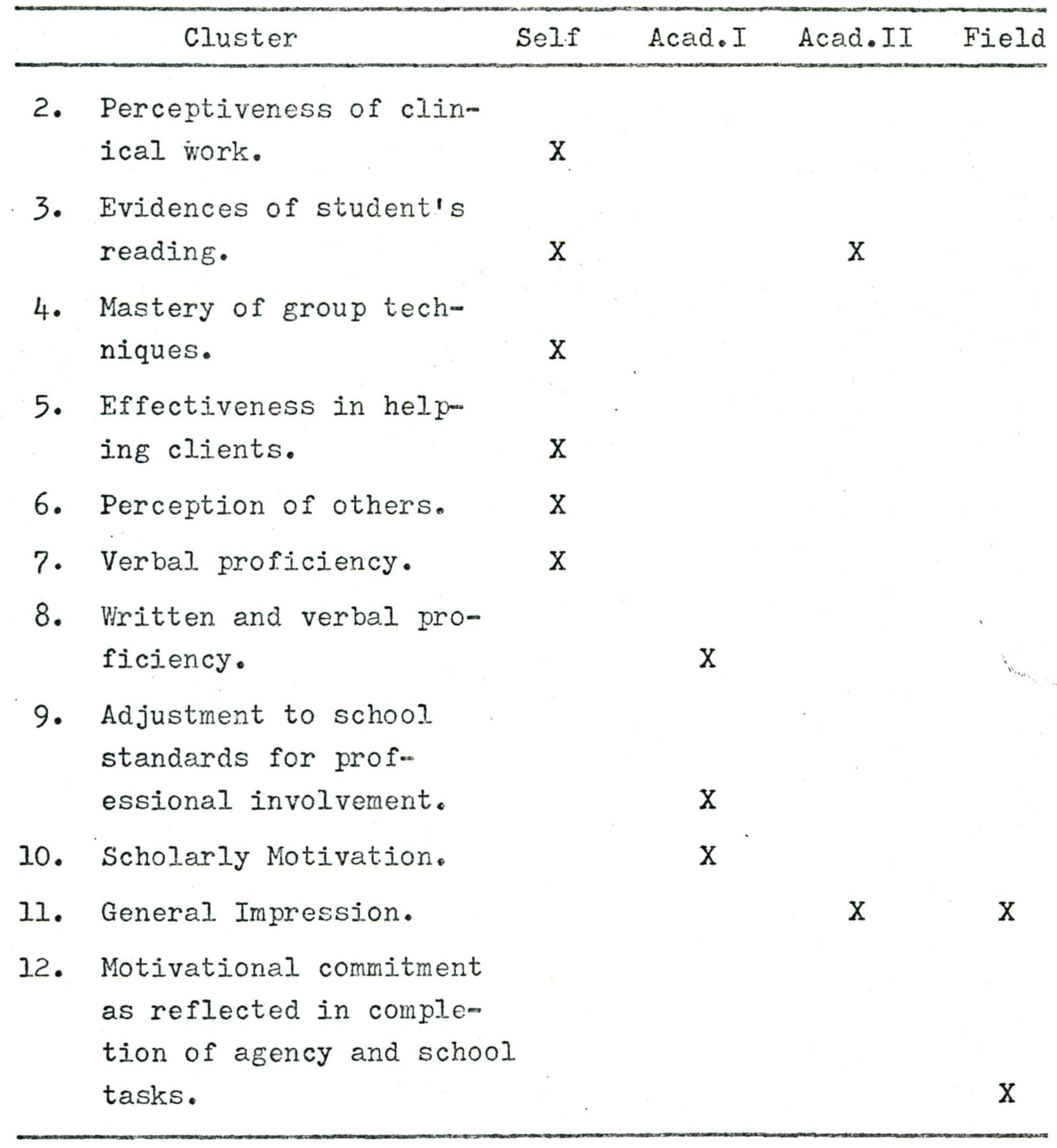

\section{SUMMARY}

A significant finding in the study was the rater's tendency to react to and thus rate the student on the basis of the general impression he creates. That this general impression tends to be positive may be a reflection of the staff's commit- 
ment to supporting and encouraging the siudents in their desire to enter the profession.

Further there is the indication that those who discriminated more sharply among their ratings on different behaviors may be more objective because their exposure to the student has been less personal in nature. Thus it appeared that the instructors whose only contact with the students was in the context of the Social Welfare History class were less inclined to reflect in their responses the general impression that colored the responses of the field instructors and the methods instructors.

Student self-ratings indicated sharp discrimination in evaluating their areas of strengths and weaknesses.

A rating scale was devised to apply to each item in the questionnaire. Points along the scale were assigned numerical values from one to nine with the point reflecting the highest value falling either at the middle or the end of the continuum. There were only two questions in the questionnaire with the highest value at the mid-point of the choices. These two questions, fourteen and twenty-two, consistently failed to correlate with other items. This suggests that the raters may not have read the questions carefully but responded habitually at the same point along the continuum.

This might have been avoided had the raters been specially trained in the use of the rating scale. Training in the use of the rating scale also might have counteracted the rater's tendency to react to the general impressions created by the student. 
In conclusion, the criteria measurement used in this study would seem to be no more effective in helping faculty in discriminating between students in specifically differential ways than the Grade point average. It was not determined whem ther this was due to the items, rating, etc., or due to subjecm tive tendencies of the raters. 


\section{REFERENCE PAGE}

1. Burgess, Thomas. Miller Analogies Test and The Selection Of Social Work Students". Counseling Center Research Reports, Vol. I, No. I. (ApriI, 1966), p. 40 (Unpublished).

2. Bartlett, Harriet. "Toward Clarification And Improvement Of Social Work Practice". Journal of Social Work, Vol. 3, No. 2. (April, 1958), p. 3.

3. Robertson, Mary Ella. "Role of Students". Journal of Education For Social Work, Vol. 4, No. 1. (Spring, 1.968), p. 57.

4. Schubert, Margaret. Field Instruction In Social Casework. University of Chicago social service monographs. (1963), p. 34 .

5. Portland State College, School of Social Work. Course Offerings and General Information. (Portland, Oregon: $1969-70)$, p. $2-3$. 


\section{BIBLIOGRAPHY}

Anastasi, Anne. Fields of Applied Psychology. New York: McGraw Hill, 1964.

Bartlett, Harriett M. "Toward Clarification and Improvement of Social Work Practice." Journal of Social Work. (April, 1.958), pp. 3-5.

Burgess, Thomas. Miller Analogies Test and the Selection of Social Work Students. Unpublished paper.

Robertson, Mary Ella. Journal of Education For Social Work. "Role of Students". Spring, 1968, Vol. 4, No. I.

Schuiert, Margaret. Field Instruction in Social Casework. University of Chicago Social service monographs, 1963. formance in Field Work. University of Minnesota, 1966.

Portland State College, School of Social Work. "Course Offering and General Information". Oregon State system of Higher Education. 1966-1970. 
APPENDIX A

QUESTIONNATRE FORM

$$
\text { P.S.U. }
$$

School of Social. Work

Student Evaluation

Student

Evaluator

General Instructions: Place an $\mathrm{X}$ along the continuum at the point which best describes the students performance. The remarks along the continum are to help define the nature of the continuum and not a specific point. If you have had no opporm tunity to observe the student on a particular question, place an $\mathrm{X}$ at the appropriate space. If you have comments, a place for them is provided after each question.

1. Student's ability to remember and apply meaningfully acadentic material presented.

$\begin{array}{lllll}\text { Unacceptable } & \text { Barely } & \text { Average or } & \text { Above } \\ & \text { Acceptable Acceptable } & \text { Average } & \end{array}$

No opportunity to observe

Comments: 
2. Ability to be analytic in oral communication.

\begin{tabular}{lllll}
\hline Talks only & Able to & Shows some Good ability & Outstand- \\
in general & follow & ability to & used frequen- ing abil- \\
impressions & breakdown & particular- tly to isolate ity, always \\
& of situa. & ize situa- & elements of & able to \\
& tions into tions & situations & isolate im- \\
& elements & & & portant \\
& & & & elements in \\
& & &
\end{tabular}

No opportunity to observe

Comments:

3. Ability to be analytic in written communication.

$\begin{array}{lllll}\text { Writes only } & \text { Able to in- } & \text { Writing } & \text { Writing } & \text { Writing } \\ \text { in general } & \text { corporate } & \text { shows some } & \text { shows abi- } & \text { shows abil- } \\ \text { impressions } & \text { elements of ability to lity to in- } & \text { ity to in- } \\ & \text { situations incorporate corporate } & \text { corporate } \\ & \text { when they } & \text { some ele- } & \text { most ele- } & \text { all elements. } \\ & \text { are pointed ments of } & \text { ments with- } & \\ & \text { out } & \text { the problem } & \text { out sugges- } & \\ & & & \text { tion. }\end{array}$

No opportunity to observe

Comments: 
4. Shows originality in oral communication.

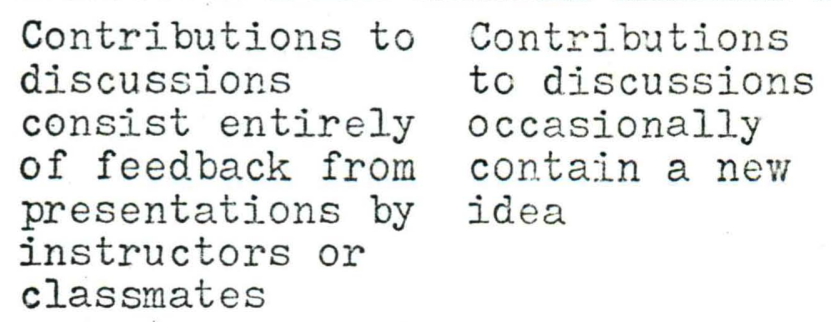

No opportunity to observe

Comments;

Is always contributing new points of view insights or questions to discussions

5. Shows originality in written communication.

\section{Papers look as if recon- structed from notes and references}

Papers show minimal amount of original thought
Papers occasionally show new ideas.

Papers
often show
new ways
of dealing
with the
material

Papers consistently in.. corporate new or surprising ways of dealing with the material

No opportunity to observe

Comments: 
6. Intelligibility of oral communication.

\begin{tabular}{|c|c|c|c|c|}
\hline $\begin{array}{l}\text { Others must } \\
\text { always ask } \\
\text { for clarif-.- } \\
\text { ication }\end{array}$ & $\begin{array}{l}\text { Others must } \\
\text { nearly al- } \\
\text { ways ask } \\
\text { for clarif- } \\
\text { ication }\end{array}$ & $\begin{array}{l}\text { Occasional } \\
\text { confusion } \\
\text { and/or } \\
\text { misunder-- } \\
\text { standing }\end{array}$ & $\begin{array}{l}\text { Others nearly } \\
\text { always under- } \\
\text { stand what he } \\
\text { orally commun- } \\
\text { icates }\end{array}$ & $\begin{array}{l}\text { Others al- } \\
\text { ways dis-- } \\
\text { cern corr- } \\
\text { ectIy and } \\
\text { confidently } \\
\text { while orally } \\
\text { comrunicat- } \\
\text { ing with him }\end{array}$ \\
\hline
\end{tabular}
No opportunity to observe

Corments:

7. Intelligibility of written communication.

$\begin{array}{lll}\text { Most writ- } & \text { Writing is } & \text { Writing is } \\ \text { ing is } & \text { mainly but } & \text { average but } \\ \text { either non- } & \text { not entire- } & \text { occasion- } \\ \text { sensical, } & \text { ly confusing } & \text { ally diffi- } \\ \text { gibberish } & & \text { cult to } \\ \text { or incom- } & & \text { understand } \\ \text { prehensible } & & \end{array}$
prehensible

$\begin{array}{ll}\text { Writing is } & \text { Writes } \\ \text { about aver- } & \text { cleariy } \\ \text { age and } & \text { simply and } \\ \text { nearly al- } & \text { directy; } \\ \text { ways compre- } & \text { Is approp- } \\ \text { hensible } & \text { riate and } \\ & \text { easy to } \\ & \text { understand }\end{array}$

No opportunity to observe

Comments: 
8. Conformity to conventions regarding organization, citations and footnotes of written material.

Shows nearly no conformity to

the conventions of writing style
Occasionally conforms to writing style conventions
Written material conforms entirely to conventions regarding style.

No opportunity to observe

Comments:

9. Neatness of Manuscripts. (typographical errors, strikeovers, submission or original copy, etc.)

Papers always contain errors, strikeovers and a disordered appearance
Papers often contajn errors, strikeovers and a disordered appearance
Papers are usually neat but at times contain some disorder in appearance
Papers contain no errors, strikeovers or disordered appearance; are always very neat No opportunity to observe

Comments: 
10. Conformity to conventions regarding spelling, grammar, word usage, etc.

Papers always
contain errors
in spelling,
grammar, and
word usage

\section{Comments:}

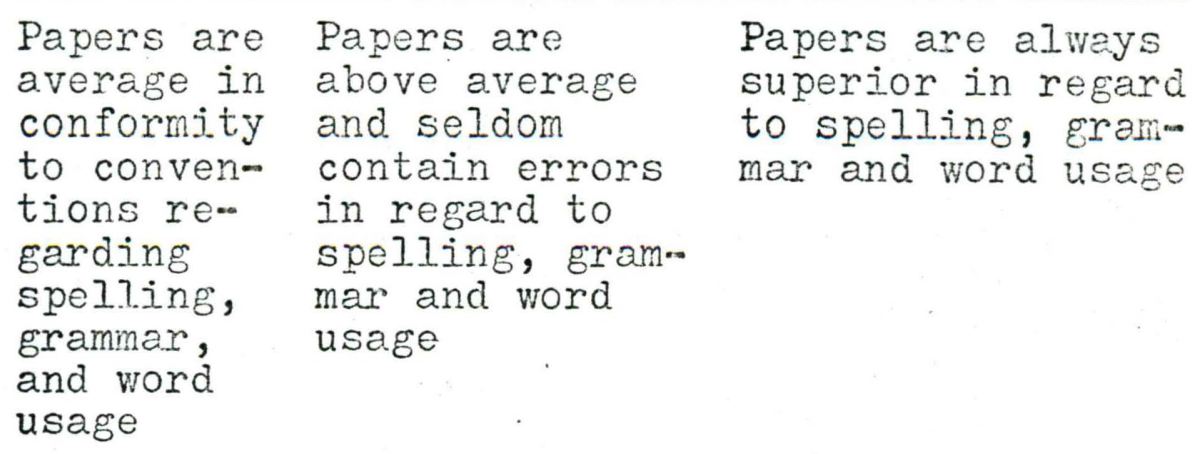

Papers are always superior in regard to spelling, eram mar and word usage

No opportunity to observe

11. Eagerness for suggestions.

$\begin{array}{ll}\text { Avoids most } & \text { Accepts infor- } \\ \text { information } & \text { mation and sug- } \\ \text { on quality of } & \text { gestions when } \\ \text { work or sug- } & \text { offered } \\ \text { gestions for } & \\ \text { modification } & \end{array}$

No opportunity to observe
Sometimes takes

the initiative

for information

and suggestions

on his work
Always seeks

feedback on his work

\section{Comments:}


12. Use of suggestions.

$\begin{array}{lllll}\text { Rejects all } & \text { Rejects most } & \text { Acts on } & \text { Acts on most } & \text { Acts in } \\ \text { suggestions } & \text { suggestions } & \text { some sug- } & \text { suggestions } & \text { some reas- } \\ & \text { or acts in- } & \text { gestions } & \text { appropriately } & \text { onable way } \\ \text { appropriately } & & & \text { on all sug- } \\ \text { on those } & & & \text { gestions } \\ \text { accepted } & & & \text { received }\end{array}$
No opportunity to observe

Comments:

13. Frequency of students demands for consultation or expicit detailed assignments.

\begin{tabular}{|c|c|c|c|c|}
\hline $\begin{array}{l}\text { Does not } \\
\text { seek enough } \\
\text { consultation } \\
\text { and muddles } \\
\text { along with- } \\
\text { out adequate } \\
\text { understanding } \\
\text { of directions }\end{array}$ & $\begin{array}{l}\text { Student } \\
\text { seeks some } \\
\text { consulta- } \\
\text { tion, but } \\
\text { tends to } \\
\text { muddle al-- } \\
\text { ong with- } \\
\text { out adequate } \\
\text { understanding } \\
\text { of directions }\end{array}$ & $\begin{array}{l}\text { Student } \\
\text { clarifies, } \\
\text { accepts } \\
\text { and uses } \\
\text { assignments } \\
\text { realisti- } \\
\text { cally }\end{array}$ & $\begin{array}{l}\text { Student } \\
\text { seeks more } \\
\text { than ade- } \\
\text { quate in- } \\
\text { struction } \\
\text { on assign- } \\
\text { ments }\end{array}$ & $\begin{array}{l}\text { Student } \\
\text { is defen- } \\
\text { sively } \\
\text { dependent } \\
\text { and always } \\
\text { requires } \\
\text { detailed } \\
\text { directions }\end{array}$ \\
\hline
\end{tabular}

__ No opportunity to observe

Comments: 
14. Frequency of reasoned disagreement with professor.

\begin{tabular}{lllll}
\hline Accepts & Student & Student & Student & Disagrees \\
everything & questions & expresses & disagrees & with every- \\
without & only on & reasoned & more than & thing without \\
question & rare & disagree- & is appro- & reasonable \\
& occasions & ment with & priate & justification \\
& & professor & & \\
& & phen appro- & &
\end{tabular}

No opportunity to observe

Comments:

15. Acceptance of relevant portions of the curriculum.

Resistive to
most portions
of the curri-
culum
culum
Accepts nearly a.l. new ideas and learning opportunities and with some resistance
Seeks and responds enthusiastically to new ideas and learning opportunities

No opportunity to observe

Comments: 
16. Constructive relationships with instructors.

\begin{tabular}{llll}
\cline { 3 - 4 } Student appears & Students rela- & Student gen- & Student al- \\
fearful of & tionship with & erally relates & ways relates \\
entering into & instructors is & well to in- & spontaneously \\
constructive & guarded and shows & structors & positively \\
relationships & no personal in- & & and maintains \\
with instruc- & volvement & & a constructive \\
tors & & & relationship
\end{tabular}

No opportunity to observe

Comments:

17. Constructive relationships with peers.

\begin{tabular}{lllll}
\hline Relationships & Relationships & Student & Student & Student is \\
with peers are & with peers & blends & gets along & well liked \\
destructive & are generally & in and & with most & and suppor- \\
& annoying but & is "just & individual & tive; il- \\
at times & one of & and is usu- ways main-a \\
& acceptable & the & ally spon- & tains a \\
& & group" & taneous and construc- \\
& & positive & tive rela- \\
& & & tionship \\
& & & & with peers
\end{tabular}

No opportunity to observe

Comments: 
18. Consistency in communication with others

$\begin{array}{lllll}\text { Verbal and } & \text { Verbal and } & \text { Verbal and } & \text { Verbal and } & \text { Verbal and } \\ \text { behavioral } & \text { behavioral } & \text { behavioral behavioral behavioral } \\ \text { messages } & \text { messages } & \text { messages } & \text { messages } & \text { messages } \\ \text { are con- } & \text { are mainly } & \text { are usually are sincere, are always } \\ \text { flictual } & \text { but not } & \text { consistent } & \text { consjstent, honest and } \\ & \text { entirely } & \text { but at } & \text { and seldom consistent } \\ & \text { in conflict times are conflictual } & \\ & & \text { conflictual } & \end{array}$

No opportunity to observe

Comments:

19. Accuracy of student's perception of other students.

$\begin{array}{lllll}\text { Student's } & \text { Student's } & \text { Student's } & \text { Student's } & \\ \text { perception } & \text { perception } & \text { perception } & \text { perception perception } \\ \text { is inaccur- } & \text { is gener- } & \text { is at times } & \text { is nearly } & \text { is always } \\ \text { ate } & \text { ally nega- } & \text { accurate and always } & \text { observant, } \\ & \text { tive and } & \text { at times in- accurate } & \text { correct } \\ & \text { inaccurate } & \text { accurate } & & \text { and know- } \\ & \text { but at times } & & & \text { ledgeable } \\ & \text { shows signs } & & & \end{array}$

No opportunity to observe

Comments: 
20. Accuracy of student's perception of instructors and supervisors.

$\begin{array}{lll}\text { Student's } & \text { Student's } & \text { Student's } \\ \text { perception } & \text { perception } & \text { perception } \\ \text { is inaccur- } & \text { is gener- } & \text { is at times } \\ \text { ate. } & \text { ally nega- } & \text { accurate and } \\ & \text { tive and } & \text { at time in- } \\ & \text { inaccurate } & \text { accurate } \\ & \text { but at times } & \\ & \text { shows signs } & \\ & \text { of accuracy }\end{array}$

$\begin{array}{ll}\text { Student's } & \text { Student's } \\ \text { perception } & \text { perception } \\ \text { is nearly } & \text { is always } \\ \text { always } & \text { observant, } \\ \text { accurate } & \text { correct } \\ & \text { and know- } \\ & \text { ledgeable }\end{array}$

No opportunity to observe

Comments:

21. Accuracy of student's perception of clients.

\begin{tabular}{ll}
\hline Student's & Student's \\
perception & perception \\
is inaccur- & is genera- \\
ate & lly nega- \\
& tive and \\
& inaccurate \\
& but at times \\
& shows signs \\
& of accuracy
\end{tabular}

Student's
perception
is at times
accurate and
at times in-
accurate
accurate

No opportunity to observe

$\begin{array}{ll}\text { Students } & \text { Student's } \\ \text { perception } & \text { perception } \\ \text { is nearly } & \text { is always } \\ \text { always } & \text { observant } \\ \text { accurate } & \text { correct } \\ & \text { and know- } \\ & \text { ledgeable }\end{array}$

Student's Student's perception perception is nearly is always always observant and knowledgeable

Comments: 
22. Ability to examine self.

\begin{tabular}{lll}
\hline Completely & Shows very & Willing \\
oblivious & little abi- & and able \\
to self & lity to & to exam- \\
& examine self & ine self \\
& &
\end{tabular}

$\begin{array}{ll}\text { At times } & \text { Examines } \\ \text { examines } & \text { selfob- } \\ \text { self too } & \text { sessively } \\ \text { much, but } & \text { and over- } \\ \text { not obses- } & \text { critically } \\ \text { sively } & \end{array}$

No opportunity to observe

Comments:

23. Accuracy of student's perception of interaction in a formed group when a participant.

Consistently

fails to

observe formed

group interaction
Student at times perceives interaction accurately and at times inaccurately
Student consistently shows a. high degree of accuracy in perceiving interaction in a formed group

No opportunity to observe

Comments: 
24. Accuracy of student's perception of interaction in a formed group when an observer.

ConsistentIy

fails to

observe formed

group interaction
Student at times perceives interaction accurately and at times inaccurately
Student consistently shows a high degree of accuracy in perm ceiving interaction in a formed group

No opportunity to observe

Comments:

25. Accuracy of student's perception of interaction in a formed. group when a leader.

Consistently

fails to

observe formed

group interaction
Student at times perceives interaction accurately and at times inaccurately
Student consistently shows a high degree of accuracy in perceiving interaction in a formed group.

No opportunity to observe

Comments: 
26. Accuracy of student's perception of significance of client's past life experiences as related to present functioning.

Student has
no awareness
of the signi-
ficance of
the clients
past exper-
iences
tioning

_._. No opportunity to observe

Student is usually aware of the most important implications of the clients past present func- experiences

Student is consistently aware of the implications of past history

Comments:

27. Accuracy of student's understanding of relationship with client.

Student
consistently
fails to
understand
his relation-
ship with
clients

Student's understanding of relationship is often distorted or superficial
No opportunity to observe
Student's
understanding of the rela- tionship is occasionally distorted or superficial

Student's understanding of the clientworker relationship is never distorted or superficial

Comments: 
28. Student's ability at engaging client's participation.

Student
consistentIy
fails to
engage clients
participation

Comments:

\begin{tabular}{ll}
\hline Student & Students \\
engages & engaging \\
clients & of clients \\
partici- & is at times \\
pation & adequate \\
rarely or & and at \\
inappro- & times in- \\
priately & adequate
\end{tabular}

Student often engages client in appropriate participation
Student in an imaginative and flexible way engages clients in relevant participation

No opportunity to observe

29. Student's ability to recognize client's strengths as well as weaknesses in problem solving process.

Student's inab-
ility to recog-
nize clients
capacity causes
lack of under-
standing and
impedes clients
in pursuing the
problem solving
process

Student at times fails to recognize clients capacity which tends to dis.. courage clients confidence in his own capacity
Studentis recognition of clients capacity neither motivates nor retards the client
Student's recog nition of clients capacity is al-. ways accurate, encouraging and realistic No opportunity to observe

Comments: 
30. Student's attitude towards his clients.

$\begin{array}{ll}\text { Student's } & \text { Student's attitude } \\ \text { attitude } & \text { is usually incon- } \\ \text { is hostile, sistent with } \\ \text { punitive } & \text { occasional indi- } \\ \text { and ambiva- cations of } \\ \text { Ient } & \text { acceptance }\end{array}$

No opportunity to observe

$\begin{array}{ll}\text { Student's attitude } & \text { Student's } \\ \text { is usually posi- } & \text { attitude is } \\ \text { tive but at times } & \text { totally } \\ \text { naive, negative } & \text { accepting, } \\ \text { and ambivalent } & \text { emphatic, but } \\ & \text { without dis- } \\ & \text { tortions }\end{array}$

Student's attitude attitude is totally accepting, emphatic, but tortions

Comments:

31. Professional purposefulness in contacts with clients.

$\begin{array}{ll}\text { In student's } & \text { Student's contacts } \\ \text { contacts } & \text { with clients is } \\ \text { with clients } & \text { usually social and } \\ \text { a goal is } & \text { not goal directed }\end{array}$ rarely evident No opportunity to observe
Student's contacts with clients are usually goal directed
Student does an excellent job in showing goals in contacts with clients

Comments: 
32. Student's overall performance in service to clients.

\begin{tabular}{llll}
\hline Student's & Student's & Student shows & Student's \\
performance & performance & many good & performance \\
is consis- & fulfills & qualities in & is excellent \\
tently poor & minimum & giving service & while giving \\
& service to & to his clients & service to \\
& clients & &
\end{tabular}

No opportunity to observe

Comments:

33. Estimate of student's helpfulness to clients.

Student re-
tards client's
progression in
solving prob-
lems

lems

$\begin{array}{lll}\text { Student's assis- } & \text { Student's assis- All of stu- } \\ \text { tance shows } & \text { tance causes } & \text { dent's cli- } \\ \text { little evidence } & \text { progressive } & \text { ent's show } \\ \text { of movement for } & \text { movement in } & \text { substantial } \\ \text { the client's } & \text { some client's } & \text { forward move- } \\ \text { progression in } & \text { problem solving ment in prob- } \\ \text { solving problems } & & \text { lem solving }\end{array}$

No opportunity to observe

Comments: 
34. Student's management of work load.

\begin{tabular}{ll}
\hline Student & Student \\
exhibi.ts & seeks more \\
very poor & than ade- \\
management & quate help \\
of his & in the man- \\
work load & agement of \\
& his work \\
& load
\end{tabular}

Comments:

$\begin{array}{lll}\text { Student } & \text { Student's } & \text { Student does } \\ \text { clarifies } & \text { management } & \text { an excellent } \\ \text { and accepts } & \text { of his work job with his } \\ \text { the manage- } & \text { load ordin- } & \text { work load } \\ \text { ment of his } & \text { arily is } & \text { and requires } \\ \text { work load, } & \text { good and } & \text { no assistance } \\ \text { but does } & \text { rarely re- } & \\ \text { need some, quires check- } \\ \text { assistance } & \text { ing by his } \\ & \text { supervisor }\end{array}$

No opportunity to observe 
36. Evidence student gives of completing recommended reading.

$\begin{array}{llll}\text { No evidence } & \text { Evidence of } & \text { Evidence of } & \text { Evidence of } \\ \text { of doing } & \text { doing some } & \text { doing most } & \text { doing all } \\ \text { recommended } & \text { recommended } & \text { recommended } & \text { recommended } \\ \text { reading } & \text { reading } & \text { reading } & \text { reading }\end{array}$

No opportunity to observe

Comments:

37. Evidence student gives of doing un-mentioned reading.

No evidence of doing un-mentioned. reading
Evidence of doing some un-mentioned reading
Evidence of doing a lot of outsjde reading.

No opportunity to observe

Comments: 
38. Student's ability to handle clients feelings about a problem.

\begin{tabular}{llll}
\hline Student & Student is & Student at & Student always \\
exhibits & somewhat & times handles & handles clients \\
inability & inconsistent & clients feel- & feelings with \\
in hand- & in handling & ings correctly & empathy and \\
ling the & clients feel- & and usualy is & in terms of the \\
clients & ings and does & client oriented & clients needs \\
feelings & not show much & & \\
about the & sensitivity & & \\
problem by & or empathy & & \\
attempting & & & \\
to meet his & & & \\
own needs & & & \\
and not the & & & \\
clients & & &
\end{tabular}

__ No opportunity to observe

Comments:

39. Student's ability to inform clients of resources from other social agencies.

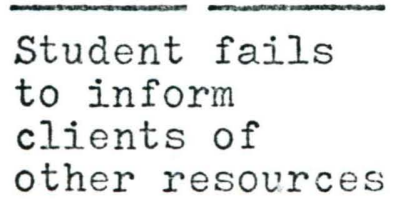

Student's
information
seems to
impede clients
use of resources

Student's information seems to use of resources
Student is generally helpful in informing clients of the resources from other agencies
Student's information about resources is always accurate, well-timed and relevant to the problem

No opportunity to observe

Comments: 
40. Accuracy of student's perception of clients social needs.

Student con-
sistently
fails to ob-
serve real
needs of
client

Student's perception is at times accurate and at times inaccurate
Student usually sees beyond the obvious for

clients needs

Student con-
sistently
shows a high
degree of
accuracy in
perceiving
the needs of
the client

Student consistently shows a high degree of accuracy in perceiving the client

No opportunity to observe

Comments:

41. Accuracy of student's perception of client's economic needs.

$\begin{array}{ll}\text { Student con- } & \text { Student's } \\ \text { sistently } & \text { perception } \\ \text { fails to ob- } & \text { is at times } \\ \text { serve real } & \text { accurate and } \\ \text { needs of } & \text { at times in- } \\ \text { client } & \text { accurate }\end{array}$

Student usually sees beyond the obvious for clients needs
Student consistently shows a high degree of accuracy in perceiving the needs of the client No opportunity to observe

Comments: 
42. Accuracy of student's perception about the client's feelings.

\begin{tabular}{llll}
\hline Student con- & Students per- & Student usually & Student con-- \\
sistently & ception is at & sees beyond the & sistently \\
fails to ob- & times accurate & obvious for & shows a high \\
serve real & and at times & clients feelings & degree of \\
feelings of & inaccurate & about his prob- & accuracy in \\
the client & & lems & perceiving \\
& & & the clients \\
& & feelings
\end{tabular}

- No opportunity to observe

Comments:

43. Accuracy of student's perception of family group interaction.

Student consistently

fails to observe

a.curately family

group interaction
Student's perception is at times accurate and at times inaccurate
Student consistently shows a high degree of accuracy in perceiving family interaction

__ No opportunity to observe

Comments: 
44. Student's ability to focus group on task goals.

\begin{tabular}{|c|c|c|c|c|c|}
\hline $\begin{array}{l}\text { Group shows } \\
\text { no evidence } \\
\text { of task } \\
\text { orientation }\end{array}$ & $\begin{array}{l}\text { Group shows } \\
\text { minimal focus } \\
\text { on task goals }\end{array}$ & $\begin{array}{l}\text { Group is } \\
\text { focused but } \\
\text { on a super- } \\
\text { ficial level }\end{array}$ & $\begin{array}{l}\text { Group } \\
\text { times } \\
\text { ains } \\
\text { task }\end{array}$ & $\begin{array}{l}\text { at } \\
\text { att- } \\
\text { the } \\
\text { goal }\end{array}$ & $\begin{array}{l}\text { Group is } \\
\text { usualiy } \\
\text { focused } \\
\text { and work- } \\
\text { ing on the } \\
\text { task goal. }\end{array}$ \\
\hline
\end{tabular}

No opportunity to observe

Comments:

45. Student's ability to maintain a group while encouraging the group to develop its ow unique characteristics.

Group shows
subgroups and
isolates

subgroups

Group often
shows sub-
groups and
isolates

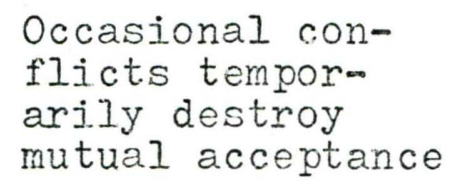

Occasional conarily destroy mutual acceptance
Group members accept each other in spite of conflicts

__ No opportunity to observe

Comments: 
46. Student's motivation in and commitment to social work.

Student shows

no motivation

and commitment
Student at times shows motivation and commitment to social work
Student appears completely committed to the field of social work

No opportunity to observe

Comments:

47. Student's ethical standards in his work.

Student has consistent and frequent problems with his ethical standards in his work
Student's ethical problems when they arise are handled and resolved satisfactorily
The student's work is always consistent with ethical standards

No opportunity to observe

Comments: 
48. Student's observance of agency policy.

\begin{tabular}{lllll}
\hline Student blindly & Student & Student at & Student & Student \\
rejects or is & rarely ob- & times ob- & usually & always \\
ignorant of & serves & serves & observes observes \\
agency policies & $\begin{array}{l}\text { agency pol- } \\
\text { icies }\end{array}$ & agency pol- & agency & agency \\
& & icies and & policies & policies \\
& & & \\
& & &
\end{tabular}

No opportunity to observe

Comments:

49. Student's contribution to agency policy development and reorganization.

$\begin{array}{ll}\text { Student never } & \text { Student rarely } \\ \text { contributes } & \text { contributes to } \\ \text { to agency } & \text { agency develop- } \\ \text { development } & \text { ment }\end{array}$

development

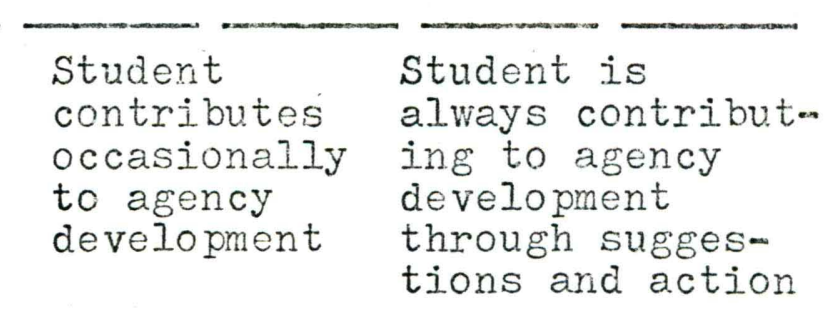

No opportunity to observe

Comments: 
50. Student's awareness of the implications of social issues to social work practices.

$\begin{array}{ll}\text { Student is } & \text { Student } \\ \text { completely } & \text { shows a } \\ \text { oblivious } & \text { minimal } \\ \text { of any im- } & \text { amount of } \\ \text { plications } & \text { awareness } \\ & \text { of impli- } \\ & \text { cations }\end{array}$

$\begin{array}{lll}\text { Student at } & \text { Student is } & \text { Student is } \\ \text { times is } & \text { usually } & \text { always } \\ \text { aware and } & \text { aware of the aware of } \\ \text { at times is } & \text { implications } & \text { the impli- } \\ \text { not aware } & & \text { cations } \\ \text { of the im- } & & \\ \text { plications } & & \end{array}$

No opportunity to observe

Comments:

51. Nature of student's reaction to opposition or conflict.

\begin{tabular}{|c|c|c|c|c|}
\hline $\begin{array}{l}\text { Student } \\
\text { always } \\
\text { becomes } \\
\text { hostile } \\
\text { and def- } \\
\text { ensive } \\
\text { when } \\
\text { opposed }\end{array}$ & $\begin{array}{l}\text { Student } \\
\text { usually } \\
\text { is hos- } \\
\text { tile and } \\
\text { defensive } \\
\text { when op- } \\
\text { posed }\end{array}$ & $\begin{array}{l}\text { Student } \\
\text { occasion- } \\
\text { ally be- } \\
\text { comes } \\
\text { hostile } \\
\text { and def- } \\
\text { ensive } \\
\text { when op- } \\
\text { posed }\end{array}$ & $\begin{array}{l}\text { Student } \\
\text { seldom } \\
\text { becomes } \\
\text { hostile } \\
\text { and def- } \\
\text { ensive } \\
\text { when op- } \\
\text { posed }\end{array}$ & $\begin{array}{l}\text { Student } \\
\text { accepts } \\
\text { and inte- } \\
\text { grates } \\
\text { properly } \\
\text { any oppo- } \\
\text { sition or } \\
\text { conflict }\end{array}$ \\
\hline
\end{tabular}

No opportunity to observe

Comments: 


\section{APPENDIX B}

CORREIATION MATRTX OF ITEMS

\section{SELF-RATINGS}

Variable No.

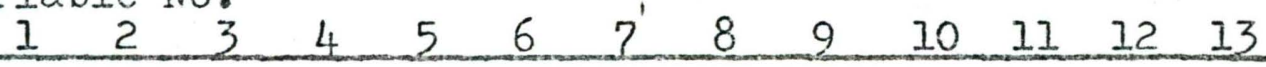

1100

245100

$350 \quad 46100$

$\begin{array}{lllll}4 & 37 & 52 & 36 & 100\end{array}$

$\begin{array}{llllll}5 & 59 & 35 & 71 & 54 & 100\end{array}$

$\begin{array}{lllllll}6 & 35 & 49 & 36 & 32 & 26 & 100\end{array}$

$\begin{array}{llllllll}7 & 37 & 05 & 53 & -11 & 42 & 16 & 100\end{array}$

$\begin{array}{lllllllll}8 & 45 & 20 & 48 & .04 & 32 & 08 & 43 & 100\end{array}$

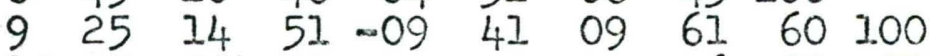

$\begin{array}{lllllllllll}10 & 37 & 00 & 53 & -05 & 40 & 04 & 46 & 73 & 57 & 100\end{array}$

$\begin{array}{llllllllllll}11 & 02 & 04 & 08 & -03 & 09 & 09 & 09 & 16 & 17 & 15 & 100\end{array}$

$\begin{array}{lllllllllllll}12 & 18 & 26 & 25 & 25 & 20 & 41 & 20 & 28 & 28 & 18 & 45 & 100\end{array}$

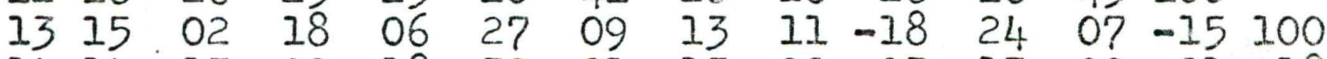

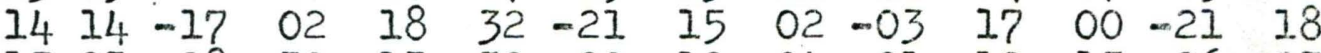

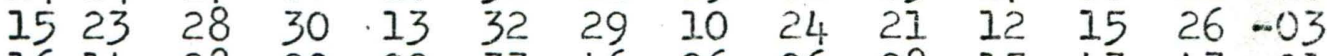

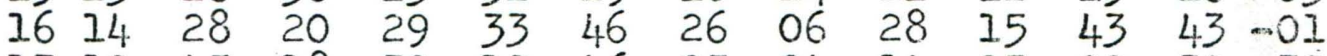

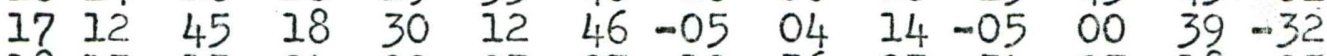

$\begin{array}{lllllllllllllll}18 & 13 & 13 & -24 & 02 & -07 & 27 & -12 & -36 & -07 & -34 & 07 & 18 & -25\end{array}$

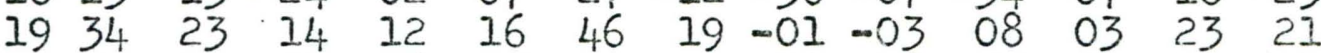

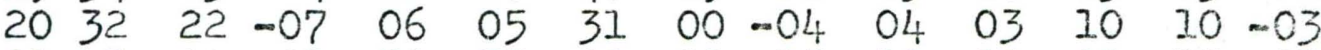

$\begin{array}{llllllllllllll}21 & 43 & 2.4 & 21 & 30 & 35 & 29 & 20 & 15 & 10 & 11 & 00 & 13 & 01\end{array}$

$\begin{array}{lllllllllllllll}22 & 14 & 14 & 03 & 02 & -12 & 33 & 04 & -12 & 10 & -06 & -21 & -08 & -23\end{array}$

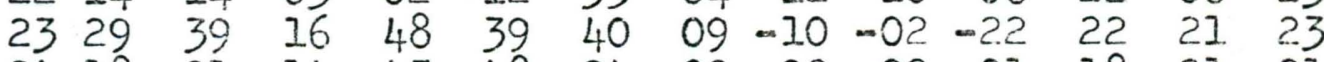

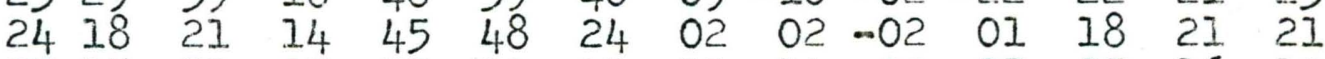

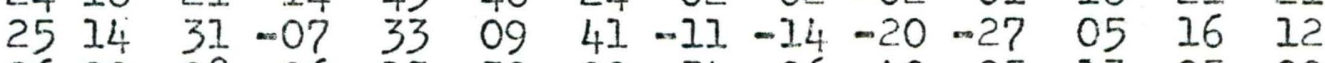

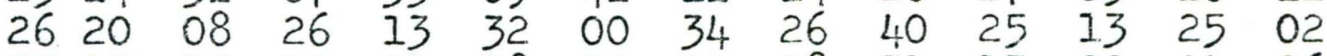

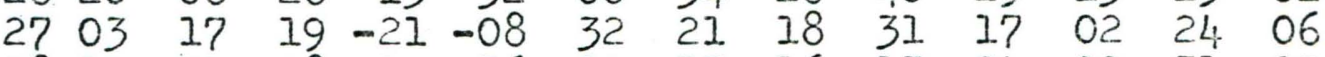

$\begin{array}{llllllllllllll}28 & 10 & 31 & 28 & 39 & 36 & 29 & 15 & 16 & 13 & 24 & 09 & 31 & 22\end{array}$

$\begin{array}{llllllllllllll}29 & 26 & 02 & 09 & 03 & 15 & 09 & 27 & -03 & 20 & 10 & 02 & -09 & -01\end{array}$

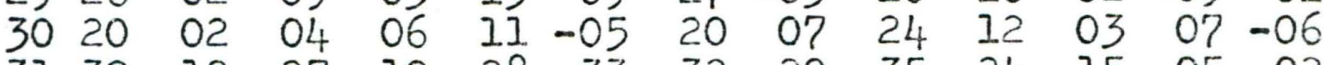

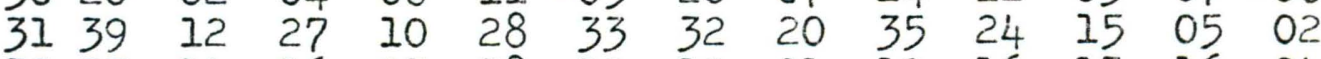

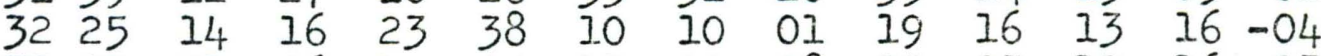

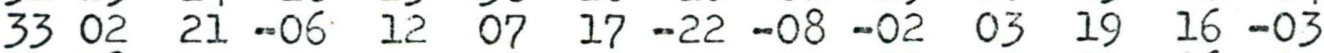

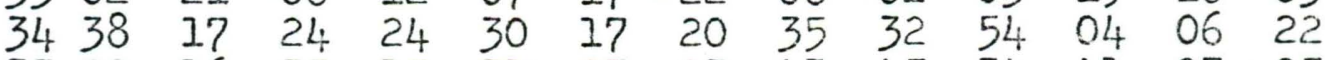

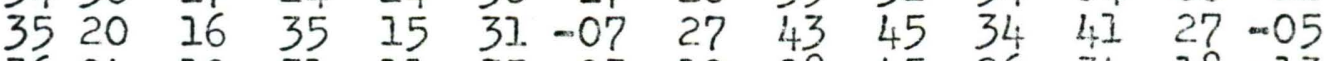

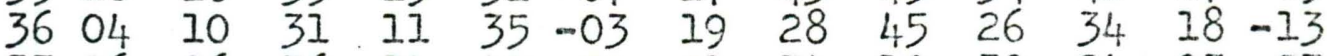

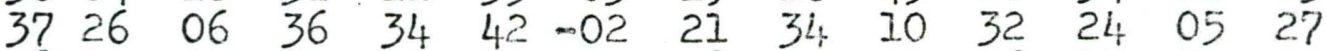

$\begin{array}{llllllllllllll}38 & 14 & 19 & 01 & 21 & 17 & 30 & 08 & 00 & 21 & 06 & 17 & 30 & 05\end{array}$ 


\begin{tabular}{|c|c|c|c|c|c|c|c|c|c|c|c|c|}
\hline $\begin{array}{c}\text { Variab } \\
I\end{array}$ & $\begin{array}{l}1 e^{N C} \\
2\end{array}$ & & 4 & 5 & 6 & 7 & 8 & 9 & 10 & 17 & 12 & 13 \\
\hline $\begin{array}{ll}39 & 31 \\
40 & 25 \\
41 & 30 \\
42 & 33 \\
43 & 32 \\
44 & 25 \\
45 & 38 \\
46 & 00 \\
47 & 26 \\
48 & 18 \\
49 & 05 \\
50 & 11 \\
51 & 10\end{array}$ & $\begin{array}{l}30 \\
24 \\
07 \\
07 \\
09 \\
35 \\
42 \\
08 \\
01 \\
14 \\
19 \\
15 \\
25\end{array}$ & $\begin{array}{l}26 \\
11 \\
23 \\
23 \\
21 \\
12 \\
25 \\
23 \\
07 \\
15 \\
12 \\
18 \\
05\end{array}$ & $\begin{array}{r}19 \\
30 \\
35 \\
37 \\
15 \\
14 \\
50 \\
00 \\
07 \\
-09 \\
34 \\
20 \\
08\end{array}$ & $\begin{array}{l}32 \\
29 \\
34 \\
40 \\
19 \\
25 \\
40 \\
08 \\
12 \\
15 \\
19 \\
22 \\
09\end{array}$ & $\begin{array}{l}20 \\
12 \\
07 \\
31 \\
16 \\
18 \\
42 \\
-05 \\
23 \\
02 \\
24 \\
15 \\
38\end{array}$ & $\begin{array}{l}24 \\
22 \\
14 \\
29 \\
37 \\
25 \\
17 \\
13 \\
31 \\
23 \\
-04 \\
24 \\
13\end{array}$ & $\begin{array}{r}20 \\
1.5 \\
05 \\
05 \\
-07 \\
33 \\
44 \\
25 \\
32 \\
25 \\
-26 \\
-00 \\
-09\end{array}$ & $\begin{array}{l}20 \\
13 \\
09 \\
10 \\
03 \\
21 \\
14 \\
35 \\
35 \\
41 \\
-04 \\
09 \\
21\end{array}$ & $\begin{array}{r}24 \\
10 \\
19 \\
14 \\
08 \\
13 \\
25 \\
29 \\
23 \\
41 \\
-14 \\
03 \\
-06\end{array}$ & $\begin{array}{r}16 \\
02 \\
01 \\
08 \\
13 \\
24 \\
28 \\
16 \\
09 \\
25 \\
-13 \\
10 \\
46\end{array}$ & $\begin{array}{r}20 \\
02 \\
07 \\
17 \\
-07 \\
09 \\
27 \\
17 \\
14 \\
21 \\
04 \\
26 \\
22\end{array}$ & $\begin{array}{r}35 \\
17 \\
25 \\
19 \\
15 \\
03 \\
23 \\
-15 \\
-17 \\
07 \\
03 \\
14 \\
-08\end{array}$ \\
\hline
\end{tabular}




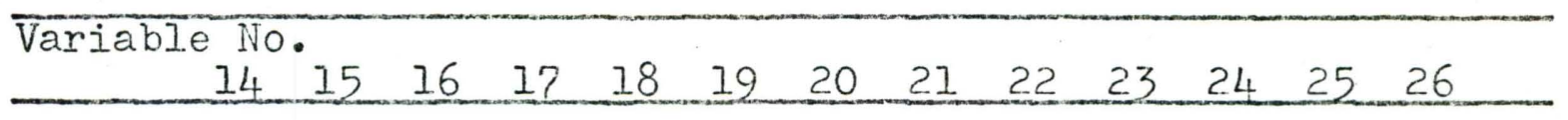

14100

1505100

$\begin{array}{llll}16 & 28 & 37 & 100\end{array}$

$\begin{array}{lllll}17 & -21 & 29 & 51 & 100\end{array}$

$\begin{array}{llllll}18 & -19 & 09 & 17 & 39 & 100\end{array}$

$\begin{array}{lllllll}19 & 12 & 02 & 18 & 26 & 32 & 100\end{array}$

$\begin{array}{llllllll}20 & 11 & 02 & 22 & 23 & 37 & 59 & 1.00\end{array}$

$\begin{array}{lllllllll}21 & 29 & 05 & 23 & 12 & 17 & 50 & 47 & 100\end{array}$

$\begin{array}{llllllllll}22 & 08 & 00 & 17 & 34 & 19 & 27 & 19 & 15 & 100\end{array}$

$\begin{array}{llllllllllll}23 & 15 & 20 & 44 & 13 & 25 & 29 & 31 & 34 & 23 & 1.00\end{array}$

$\begin{array}{llllllllllll}24 & 22 & 24 & 38 & 08 & 11 & 27 & 05 & 40 & 00 & 55 & 100\end{array}$

$\begin{array}{lllllllllllll}25 & -08 & 04 & 35 & 31 & 16 & 30 & 36 & 43 & 27 & 60 & 51 & 100\end{array}$

$\begin{array}{llllllllllllll}26 & 19 & 02 & 26 & 1.5 & 00 & 19 & 24 & 28 & 01 & 13 & 19 & 29 & 100\end{array}$

$\begin{array}{llllllllllllll}27 & -23 & 16 & 1.4 & 27 & 01 & 24 & 01 & 25 & 31 & 02 & 06 & 30 & 21\end{array}$

$\begin{array}{llllllllllllll}28 & 20 & 12 & 38 & 20 & 23 & 37 & 20 & 38 & -13 & 37 & 25 & 04 & 17\end{array}$

$\begin{array}{llllllllllllll}29 & 12 & 04 & 33 & 31 & 11 & 09 & 08 & 22 & 19 & 05 & 03 & 07 & 25\end{array}$

$\begin{array}{llllllllllllll}30 & 08 & 19 & 03 & 08 & 15 & 03 & 14 & 27 & 25 & 14 & 00 & 16 & 25\end{array}$

$\begin{array}{llllllllllllll}31 & 02 & 05 & 30 & 08 & 02 & 18 & 15 & 34 & 37 & 22 & 20 & 26 & 29\end{array}$

$\begin{array}{llllllllllllll}32 & 29 & 13 & 23 & 11 & 28 & 24 & 29 & 51 & 17 & 27 & 23 & 07 & 30\end{array}$

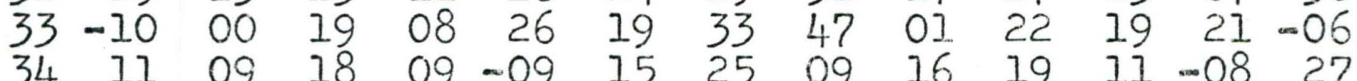

$\begin{array}{llllllllllllll}34 & 11 & 09 & 18 & 09 & -09 & 15 & 25 & 09 & 16 & 19 & 11 & -08 & 27 \\ 35 & 04 & 16 & 27 & 03 & -08 & -13 & 03 & -08 & -15 & 03 & -16 & -22 & 29\end{array}$

$\begin{array}{llllllllllllll}36 & 16 & 16 & 28 & 00 & 17 & -01 & 08 & 08 & -07 & 02 & 01 & -25 & 18\end{array}$

$\begin{array}{llllllllllllll}37 & 35 & 00 & 07 & -21 & -24 & 12 & 1.4 & 11 & -23 & 09 & 16 & -13 & 06\end{array}$

$\begin{array}{llllllllllllll}38 & 03 & 05 & 30 & 2.4 & 34 & 38 & 53 & 41 & 17 & 42 & 20 & 38 & 30\end{array}$

$\begin{array}{llllllllllllll}39 & 22 & 13 & 13 & 11 & 03 & 24 & 33 & 26 & 18 & 47 & 20 & 34 & 44\end{array}$

$\begin{array}{llllllllllllll}40 & 35 & 08 & 13 & -14 & -05 & 19 & 22 & 32 & 10 & 40 & 25 & 32 & 37\end{array}$

$\begin{array}{llllllllllllll}41 & 28 & -07 & 18 & 03 & -04 & 17 & 44 & 41 & 01 & 35 & 13 & 20 & 34\end{array}$

$\begin{array}{llllllllllllll}42 & 27 & 05 & 48 & 1.1 & -09 & 30 & 13 & 46 & 00 & 42 & 34 & 32 & 24\end{array}$

$\begin{array}{llllllllllllll}43 & 21 & 00 & 25 & 04 & -17 & 25 & 08 & 39 & 12 & 25 & 06 & 26 & 09\end{array}$

$\begin{array}{llllllllllllll}44 & 04 & 12 & 26 & 09 & 00 & 05 & 17 & 25 & 17 & 48 & 40 & 44 & 31\end{array}$

$\begin{array}{llllllllllllll}45 & 06 & 24 & 38 & 22 & -03 & 14 & 22 & 27 & 03 & 49 & 50 & 29 & 15\end{array}$

$\begin{array}{llllllllllllll}46 & 1.0 & 09 & 23 & 19 & 06 & -1.4 & 05 & 20 & 10 & -12 & -11 & -12 & 21\end{array}$

$\begin{array}{llllllllllllll}47 & 12 & -.09 & 33 & 19 & 09 & 07 & 31 & 44 & 10 & 03 & -10 & 02 & 03\end{array}$

$\begin{array}{llllllllllllll}48 & 05 & 28 & 29 & 21 & 07 & 09 & 19 & -07 & 07 & 08 & 08 & 04 & 32\end{array}$

$\begin{array}{llllllllllllll}49 & 06 & 04 & 19 & 44 & 49 & 19 & 37 & 26 & 21 & 33 & 21 & 32 & 10\end{array}$

$\begin{array}{llllllllllllll}50 & 05 & 14 & 12 & 18 & 18 & 19 & 19 & 24 & 01 & 11 & 23 & 29 & 24\end{array}$

$\begin{array}{llllllllllllll}51 & 02 & 10 & 52 & 23 & 27 & 17 & 38 & 27 & 40 & 49 & 29 & 49 & 31\end{array}$ 
Variable No 2728

27100

2804.100

$\begin{array}{llll}29 & 32 & 18 & 100\end{array}$

$\begin{array}{lllll}30 & 2.0 & 11 & 52 & 100\end{array}$

$\begin{array}{llllll}31 & 27 & 09 & 59 & 39 & 100\end{array}$

$\begin{array}{lllllll}32 & 10 & 45 & 40 & 56 & 43 & 100\end{array}$

$\begin{array}{llllllll}33 & 12 & 38 & 18 & 34 & 29 & 62 & 100\end{array}$

$\begin{array}{lllllllll}34 & 01 & 43 & 24 & 28 & 37 & 50 & 29 & 100\end{array}$

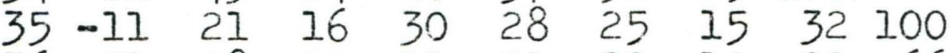

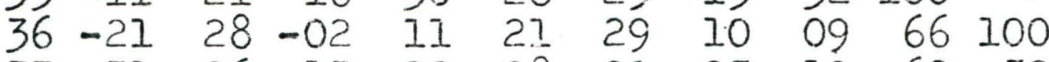

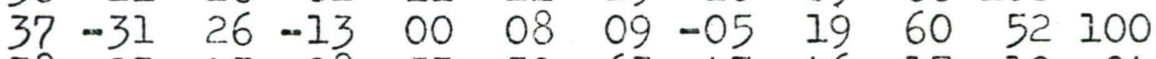

$\begin{array}{lllllllllllll}38 & 23 & 43 & 28 & 53 & 39 & 63 & 47 & 46 & 17 & 10 & 04 & 100\end{array}$

$\begin{array}{llllllllllllll}39 & 28 & 32 & 28 & 36 & 35 & 49 & 25 & 51 & 20 & 02 & 08 & 61 & 100\end{array}$

$\begin{array}{llllllllllllll}40 & 17 & 38 & 14 & 43 & 28 & 46 & 18 & 43 & 25 & 10 & 35 & 50 & 55\end{array}$

$\begin{array}{llllllllllllll}41 & 04 & 32 & 31 & 38 & 22 & 50 & 37 & 41 & 22 & 03 & 19 & 54 & 61 .\end{array}$

$\begin{array}{llllllllllllll}42 & 19 & 41 & 48 & 17 & 58 & 40 & 24 & 25 & 15 & 18 & 21 & 33 & 25\end{array}$

$\begin{array}{llllllllllllll}43 & 09 & 09 & 36 & 14 & 43 & 18 & 10 & 06 & -09 & \cdots 11 & 00 & 05 & 05\end{array}$

$\begin{array}{llllllllllllll}44 & 12 & 09 & 14 & 31 & 40 & 17 & 16 & 24 & 29 & 16 & 20 & 25 & 31\end{array}$

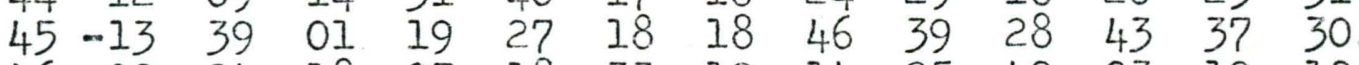

$\begin{array}{llllllllllllll}46 & 00 & 24 & 18 & 27 & 18 & 33 & 12 & 14 & 25 & 42 & 03 & 19 & 10\end{array}$

$\begin{array}{llllllllllllll}47 & 10 & 27 & 46 & 32 & 42 & 42 & 25 & 34 & 23 & 25 & 18 & 43 & 12\end{array}$

$\begin{array}{llllllllllllll}48 & 31 & 10 & 26 & 19 & 29 & 16 & 02 & 41 & 21 & 01 & -13 & 2.4 & 43\end{array}$

$\begin{array}{llllllllllllll}49 & -10 & 20 & 02 & 03 & 00 & 26 & 1.4 & 10 & -14 & 07 & 02 & 35 & 20\end{array}$

$\begin{array}{llllllllllllll}50 & 10 & 17 & 03 & 32 & 09 & 13 & -07 & -09 & 07 & 27 & 22 & 27 & 32\end{array}$

$\begin{array}{llllllllllllll}51 & 28 & 01 & 27 & 28 & 51 & 32 & 39 & 14 & 12 & 05 & -11 & 46 & 39\end{array}$ 


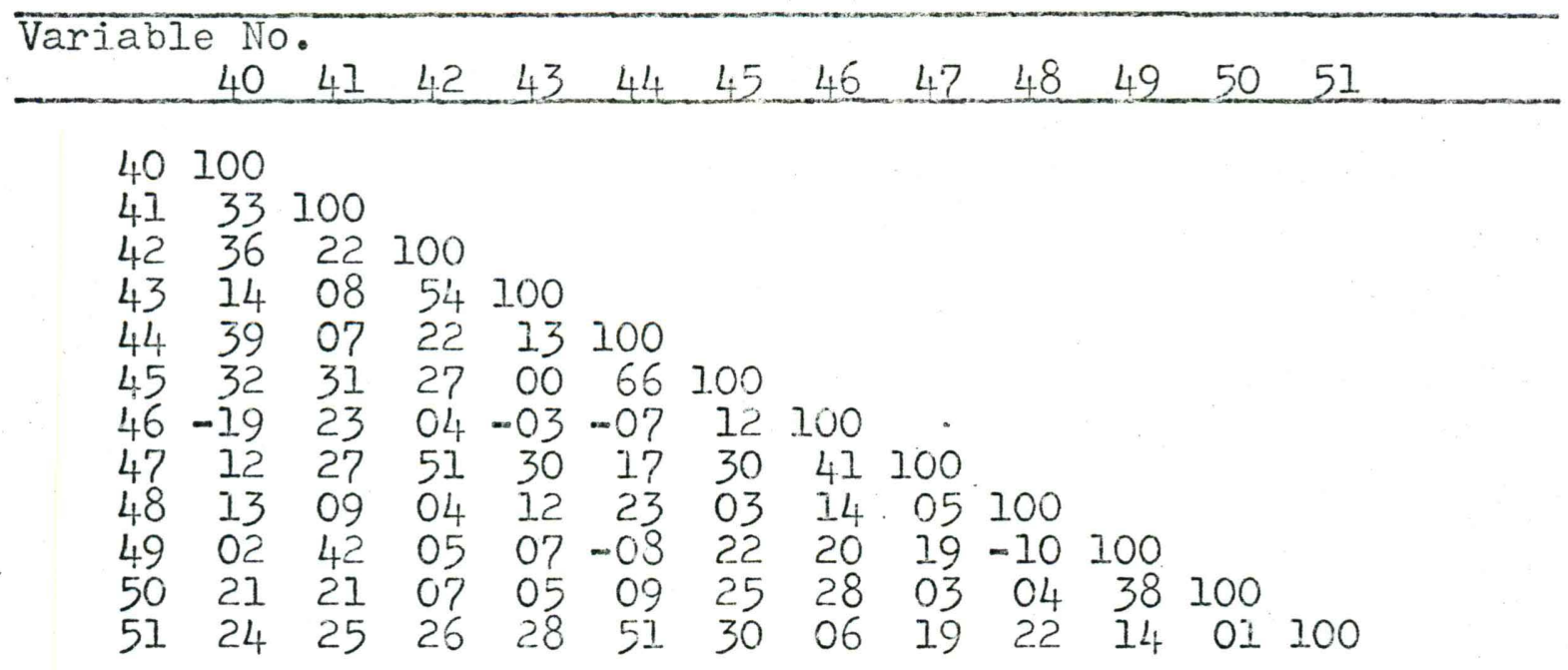


SOCIAL WELFARE RATERS

\begin{tabular}{|c|c|c|c|c|c|c|c|c|c|c|c|c|c|}
\hline aria & $1^{n}$ & 2 & 3 & 4 & 5 & 6 & 7 & 8 & 9 & 10 & 21 & 12 & 13 \\
\hline $\begin{array}{l}1 \\
2 \\
3 \\
4 \\
5 \\
6 \\
7 \\
8 \\
9 \\
10 \\
11 \\
12 \\
13 \\
14 \\
15 \\
16 \\
17 \\
18 \\
19 \\
20 \\
22 \\
35 \\
36 \\
37 \\
46 \\
47 \\
50 \\
51\end{array}$ & $\begin{array}{r}100 \\
77 \\
91 \\
60 \\
75 \\
75 \\
75 \\
50 \\
37 \\
70 \\
16 \\
34 \\
01 \\
12 \\
39 \\
34 \\
21 \\
56 \\
48 \\
46 \\
-27 \\
60 \\
42 \\
56 \\
31 \\
43 \\
39 \\
20\end{array}$ & $\begin{array}{r}100 \\
74 \\
81 \\
78 \\
84 \\
63 \\
59 \\
54 \\
54 \\
12 \\
30 \\
04 \\
23 \\
40 \\
39 \\
42 \\
50 \\
32 \\
32 \\
-18 \\
32 \\
25 \\
50 \\
22 \\
29 \\
36 \\
15\end{array}$ & $\begin{array}{r}100 \\
60 \\
78 \\
72 \\
67 \\
47 \\
33 \\
65 \\
12 \\
26 \\
07 \\
13 \\
36 \\
39 \\
15 \\
51 \\
38 \\
45 \\
-34 \\
51 \\
35 \\
49 \\
30 \\
41 \\
33 \\
14\end{array}$ & $\begin{array}{r}100 \\
81 \\
71 \\
41 \\
84 \\
73 \\
32 \\
27 \\
21 \\
02 \\
39 \\
55 \\
54 \\
58 \\
56 \\
39 \\
41 \\
-11 \\
28 \\
26 \\
61 \\
39 \\
22 \\
47 \\
19\end{array}$ & $\begin{array}{r}100 \\
66 \\
63 \\
43 \\
39 \\
52 \\
15 \\
16 \\
08 \\
37 \\
41 \\
36 \\
37 \\
57 \\
39 \\
35 \\
-27 \\
39 \\
42 \\
64 \\
27 \\
21 \\
48 \\
11\end{array}$ & $\begin{array}{r}100 \\
58 \\
58 \\
50 \\
52 \\
-04 \\
30 \\
-19 \\
30 \\
36 \\
44 \\
50 \\
69 \\
61 \\
66 \\
-02 \\
22 \\
20 \\
40 \\
32 \\
40 \\
27 \\
28\end{array}$ & $\begin{array}{r}100 \\
100 \\
100 \\
85 \\
25 \\
50 \\
09 \\
09 \\
44 \\
38 \\
04 \\
41 \\
40 \\
36 \\
-35 \\
54 \\
52 \\
52 \\
26 \\
35 \\
30 \\
08\end{array}$ & $\begin{array}{r}100 \\
96 \\
83 \\
-24 \\
58 \\
28 \\
-46 \\
87 \\
89 \\
46 \\
97 \\
93 \\
-18 \\
16 \\
12 \\
28 \\
65 \\
47 \\
63 \\
49\end{array}$ & $\begin{array}{r}100 \\
91 \\
-42 \\
70 \\
27 \\
-53 \\
90 \\
80 \\
38 \\
94 \\
88 \\
-12 \\
15 \\
47 \\
47 \\
75 \\
27 \\
45 \\
45\end{array}$ & $\begin{array}{r}100 \\
17 \\
41 \\
07 \\
01 \\
37 \\
25 \\
-08 \\
31 \\
25 \\
24 \\
-40 \\
56 \\
45 \\
44 \\
22 \\
31 \\
20 \\
02\end{array}$ & $\begin{array}{r}100 \\
41 \\
30 \\
04 \\
41 \\
36 \\
12 \\
07 \\
32 \\
23 \\
-40 \\
69 \\
43 \\
39 \\
42 \\
24 \\
54 \\
08\end{array}$ & $\begin{array}{r}100 \\
18 \\
03 \\
51 \\
41 \\
17 \\
42 \\
50 \\
56 \\
-39 \\
51 \\
35 \\
27 \\
48 \\
28 \\
35 \\
34\end{array}$ & $\begin{array}{r}100 \\
-09 \\
14 \\
23 \\
-08 \\
-26 \\
=07 \\
09 \\
-42 \\
34 \\
15 \\
13 \\
01 \\
03 \\
12 \\
-13\end{array}$ \\
\hline
\end{tabular}




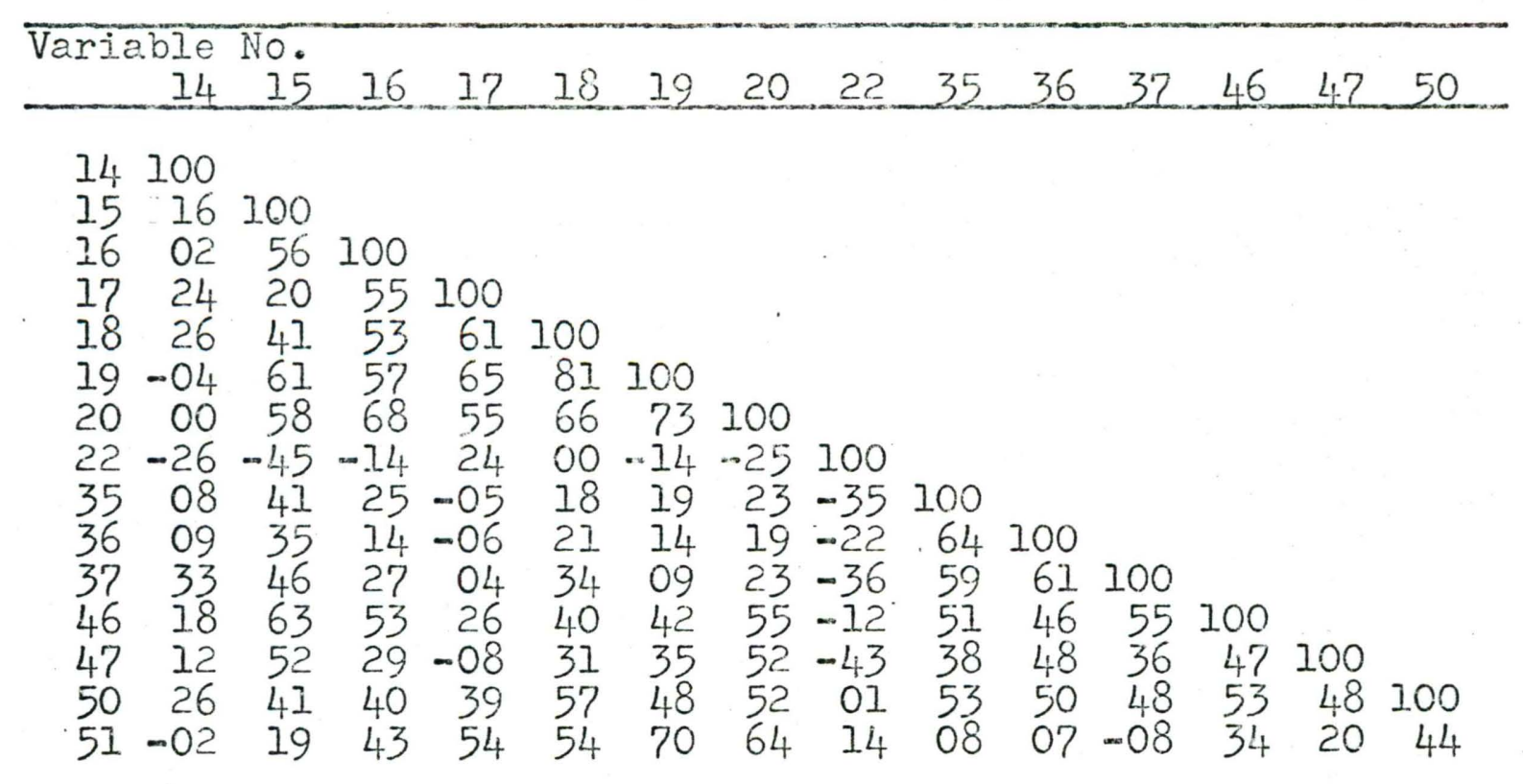


METHODS TEACHERS RATINGS

\begin{tabular}{|c|c|c|c|c|c|c|c|c|c|c|c|c|c|}
\hline $\operatorname{ariat}$ & $\begin{array}{c}\text { Ie } \\
1\end{array}$ & 2 & 3 & 4 & 5 & 6 & 2 & 8 & 9 & 20 & 11 & 12 & 13 \\
\hline 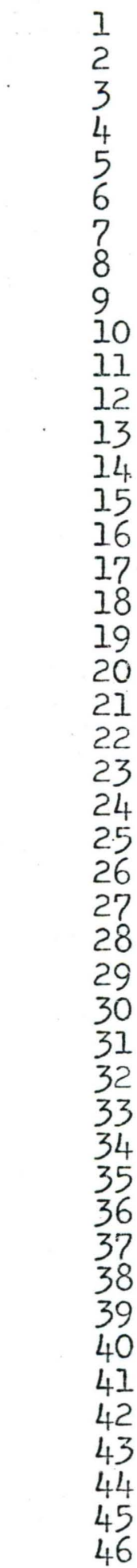 & $\begin{array}{c}100 \\
73 \\
72 \\
59 \\
79 \\
69 \\
76 \\
42 \\
49 \\
55 \\
61 \\
49 \\
11 \\
35 \\
62 \\
58 \\
47 \\
68 \\
51 \\
67 \\
58 \\
20 \\
67 \\
63 \\
62 \\
64 \\
60 \\
56 \\
50 \\
46 \\
49 \\
74 \\
63 \\
67 \\
32 \\
28 \\
39 \\
53 \\
27 \\
60 \\
42 \\
54 \\
58 \\
52 \\
56 \\
30\end{array}$ & $\begin{array}{r}100 \\
75 \\
54 \\
63 \\
79 \\
79 \\
62 \\
25 \\
54 \\
40 \\
56 \\
60 \\
23 \\
44 \\
62 \\
66 \\
54 \\
72 \\
62 \\
62 \\
71 \\
45 \\
72 \\
65 \\
66 \\
68 \\
72 \\
69 \\
65 \\
60 \\
66 \\
78 \\
73 \\
53 \\
14 \\
19\end{array}$ & $\begin{array}{l} \\
100 \\
54 \\
67 \\
65 \\
69 \\
44 \\
50 \\
49 \\
50 \\
62 \\
18 \\
43 \\
45 \\
61 \\
25 \\
54 \\
39 \\
66 \\
62 \\
71 \\
45 \\
72 \\
65 \\
66 \\
72 \\
69 \\
65 \\
60 \\
66 \\
78 \\
71 \\
57 \\
10 \\
15 \\
19 \\
68 \\
34 \\
73 \\
38 \\
67 \\
75 \\
40 \\
40 \\
19\end{array}$ & $\begin{array}{r}100 \\
70 \\
53 \\
31 \\
41 \\
20 \\
22 \\
34 \\
42 \\
12 \\
35 \\
51 \\
37 \\
17 \\
43 \\
46 \\
53 \\
60 \\
25 \\
48 \\
45 \\
33 \\
46 \\
46 \\
39 \\
35 \\
33 \\
38 \\
59 \\
50 \\
36 \\
36 \\
39 \\
27 \\
40 \\
37 \\
53 \\
34 \\
44 \\
45 \\
22 \\
20 \\
24\end{array}$ & $\begin{array}{l}100 \\
63 \\
67 \\
48 \\
47 \\
37 \\
56 \\
57 \\
544 \\
22 \\
36 \\
64 \\
64 \\
47 \\
35 \\
58 \\
53 \\
72 \\
58 \\
20 \\
20 \\
63 \\
60 \\
60 \\
58 \\
47 \\
42 \\
42 \\
42 \\
37 \\
43 \\
71 \\
59 \\
50 \\
60 \\
31 \\
38 \\
26\end{array}$ & $\begin{array}{r}100 \\
63 \\
40 \\
44 \\
41 \\
55 \\
54 \\
18 \\
46 \\
60 \\
62 \\
60 \\
74 \\
63 \\
69 \\
69 \\
43 \\
71 \\
62 \\
62 \\
68 \\
74 \\
56 \\
57 \\
52 \\
56 \\
72 \\
64 \\
51 \\
24 \\
12 \\
28 \\
56 \\
37 \\
60 \\
63 \\
70 \\
71 \\
59 \\
47 \\
42\end{array}$ & $\begin{array}{r}100 \\
59 \\
60 \\
67 \\
60 \\
52 \\
25 \\
39 \\
50 \\
61 \\
47 \\
59 \\
51 \\
68 \\
45 \\
19 \\
47 \\
48 \\
57 \\
64 \\
53 \\
51 \\
56 \\
53 \\
43 \\
69 \\
52 \\
67 \\
28 \\
18 \\
30 \\
54 \\
16 \\
59 \\
37 \\
55 \\
61 \\
64 \\
57 \\
20\end{array}$ & $\begin{array}{r}100 \\
59 \\
73 \\
54 \\
45 \\
15 \\
07 \\
51 \\
50 \\
30 \\
49 \\
43 \\
51 \\
41 \\
-28 \\
47 \\
59 \\
56 \\
45 \\
34 \\
31 \\
33 \\
29 \\
09 \\
56 \\
36 \\
49 \\
66 \\
73 \\
35 \\
35 \\
47 \\
36 \\
44 \\
66 \\
43 \\
49 \\
40 \\
54\end{array}$ & $\begin{array}{r}100 \\
49 \\
32 \\
36 \\
12 \\
25 \\
27 \\
27 \\
49 \\
37 \\
53 \\
30 \\
37 \\
26 \\
30 \\
26 \\
30 \\
21 \\
40 \\
27 \\
42 \\
27 \\
17 \\
09 \\
45 \\
25 \\
59 \\
444 \\
09 \\
26 \\
43 \\
09 \\
30 \\
25 \\
43 \\
47 \\
08 \\
47 \\
18\end{array}$ & $\begin{array}{r}100 \\
56 \\
31 \\
03 \\
29 \\
34 \\
32 \\
20 \\
41 \\
42 \\
42 \\
30 \\
-14 \\
34 \\
43 \\
30 \\
43 \\
24 \\
25 \\
27 \\
21 \\
18 \\
44 \\
39 \\
55 \\
47 \\
36 \\
28 \\
18 \\
39 \\
35 \\
44 \\
37 \\
40 \\
31 \\
37 \\
41\end{array}$ & $\begin{array}{r}100 \\
62 \\
04 \\
15 \\
15 \\
58 \\
62 \\
37 \\
52 \\
46 \\
42 \\
52 \\
51 \\
05 \\
60 \\
65 \\
67 \\
64 \\
43 \\
45 \\
52 \\
54 \\
46 \\
62 \\
53 \\
44 \\
37 \\
37 \\
40 \\
39 \\
38 \\
52 \\
50 \\
49 \\
55\end{array}$ & $\begin{array}{l}100 \\
38 \\
32 \\
55 \\
71 \\
51 \\
58 \\
55 \\
67 \\
67 \\
48 \\
55 \\
59 \\
55 \\
67 \\
63 \\
57 \\
67 \\
75 \\
60 \\
79 \\
63 \\
45 \\
20 \\
24 \\
21 \\
66 \\
21 \\
70 \\
48 \\
68 \\
66 \\
52 \\
58 \\
27\end{array}$ & $\begin{array}{r}100 \\
08 \\
32 \\
27 \\
31 \\
29 \\
41 \\
52 \\
20 \\
49 \\
16 \\
18 \\
02 \\
07 \\
39 \\
11 \\
25 \\
30 \\
30 \\
34 \\
21 \\
-04 \\
-04 \\
-18 \\
35 \\
-09 \\
22 \\
22 \\
36 \\
21 \\
02 \\
06 \\
-21 \\
-09\end{array}$ \\
\hline
\end{tabular}




\begin{tabular}{|c|c|c|c|c|c|c|c|c|c|c|c|c|c|}
\hline Variabl & $\begin{array}{l}2^{\text {No. }} \\
2^{2}\end{array}$ & 2 & 3 & 4 & 5 & 6 & 7 & 8 & 9 & 10 & 11 & 12 & 13 \\
\hline $\begin{array}{l}47 \\
48 \\
49 \\
50 \\
51\end{array}$ & $\begin{array}{l}42 \\
25 \\
59 \\
58 \\
64\end{array}$ & $\begin{array}{l}36 \\
22 \\
61 \\
59 \\
62\end{array}$ & $\begin{array}{l}21 \\
13 \\
50 \\
60 \\
54\end{array}$ & $\begin{array}{l}33 \\
00 \\
63 \\
56 \\
62\end{array}$ & $\begin{array}{l}21 \\
15 \\
57 \\
55 \\
63 .\end{array}$ & $\begin{array}{l}50 \\
23 \\
55 \\
58 \\
68\end{array}$ & $\begin{array}{l}20 \\
40 \\
44 \\
52 \\
61\end{array}$ & $\begin{array}{l}38 \\
30 \\
29 \\
66 \\
52\end{array}$ & $\begin{array}{l}1.0 \\
06 \\
50 \\
45 \\
36\end{array}$ & $\begin{array}{l}30 \\
21 \\
48 \\
31 \\
38\end{array}$ & $\begin{array}{l}40 \\
42 \\
34 \\
39 \\
42\end{array}$ & $\begin{array}{l}31 \\
30 \\
49 \\
59 \\
61\end{array}$ & $\begin{array}{r}-09 \\
14 \\
13 \\
20 \\
33\end{array}$ \\
\hline
\end{tabular}




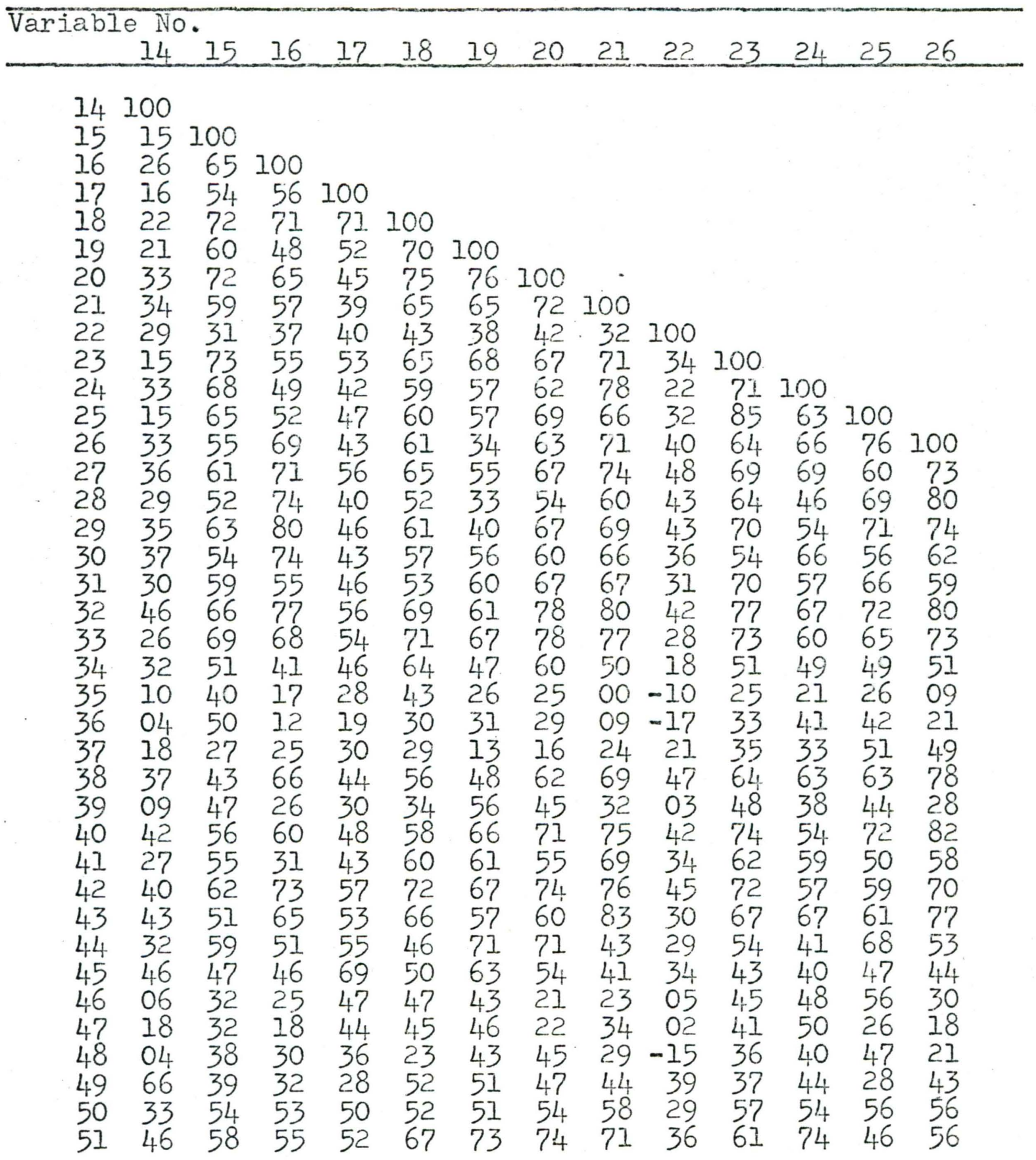




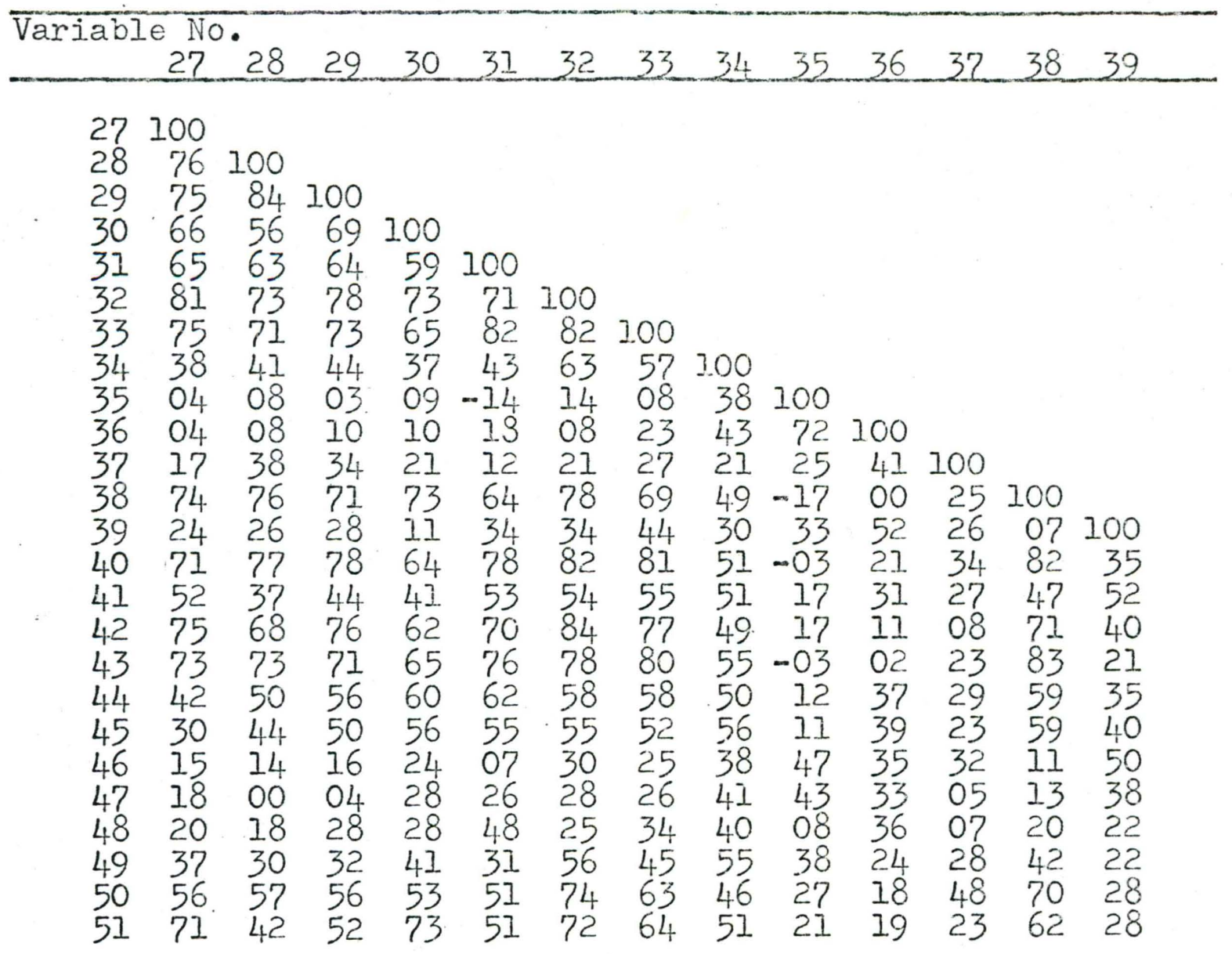




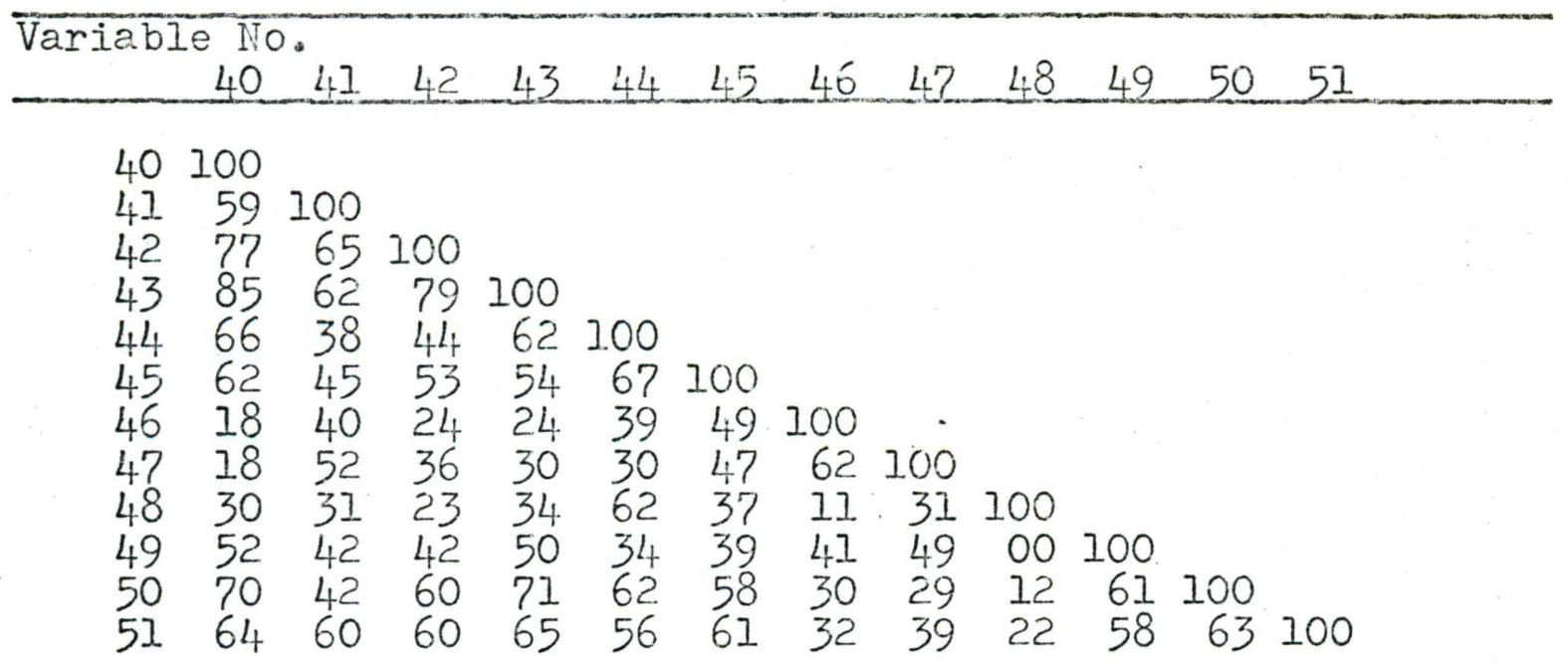




\section{FIELD INSTRUCTOR RATINGS}

\begin{tabular}{|c|c|c|c|c|c|c|c|c|c|c|c|c|c|}
\hline aria & $I^{N}$ & 2 & 3 & 4 & 5 & 6 & ? & 8 & 9 & 10 & 11 & 12 & 13 \\
\hline 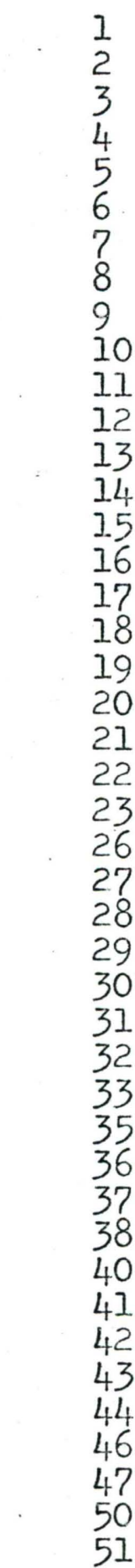 & $\begin{array}{r}100 \\
82 \\
84 \\
82 \\
70 \\
72 \\
74 \\
50 \\
4.4 \\
60 \\
43 \\
62 \\
20 \\
45 \\
58 \\
65 \\
43 \\
65 \\
71 \\
78 \\
81 \\
51 \\
80 \\
84 \\
74 \\
72 \\
70 \\
63 \\
85 \\
86 \\
82 \\
42 \\
31 \\
52 \\
71 \\
70 \\
06 \\
79 \\
74 \\
53 \\
47 \\
60 \\
59 \\
54\end{array}$ & $\begin{array}{l}100 \\
78 \\
84 \\
71 \\
71 \\
82 \\
62 \\
32 \\
32 \\
26 \\
42 \\
34 \\
47 \\
47 \\
27 \\
32 \\
49 \\
57 \\
38 \\
52 \\
82 \\
72 \\
72 \\
76 \\
52 \\
83 \\
78 \\
74 \\
74 \\
68 \\
74 \\
63 \\
73 \\
72 \\
81 \\
74 \\
33 \\
25 \\
52\end{array}$ & $\begin{array}{r}100 \\
74 \\
75 \\
71 \\
77 \\
59 \\
47 \\
66 \\
35 \\
52 \\
25 \\
46 \\
60 \\
64 \\
41 \\
56 \\
81 \\
82 \\
71 \\
50 \\
79 \\
81 \\
68 \\
62 \\
59 \\
51 \\
79 \\
72 \\
69 \\
43 \\
32 \\
56 \\
51 \\
65 \\
33 \\
68 \\
62 \\
67 \\
43 \\
58 \\
64 \\
51\end{array}$ & $\begin{array}{l}100 \\
77 \\
73 \\
59 \\
30 \\
23 \\
41 \\
39 \\
57 \\
16 \\
54 \\
61 \\
70 \\
52 \\
64 \\
65 \\
75 \\
71 \\
50 \\
74 \\
82 \\
70 \\
65 \\
71 \\
61 \\
74 \\
81 \\
75 \\
32 \\
33 \\
63 \\
64 \\
78 \\
12 \\
78 \\
71 \\
59 \\
51 \\
61 \\
69 \\
42\end{array}$ & $\begin{array}{r}100 \\
63 \\
68 \\
40 \\
40 \\
52 \\
40 \\
54 \\
22 \\
39 \\
58 \\
65 \\
39 \\
60 \\
62 \\
68 \\
67 \\
48 \\
65 \\
75 \\
61 \\
69 \\
55 \\
46 \\
73 \\
59 \\
61 \\
42 \\
48 \\
64 \\
72 \\
62 \\
25 \\
64 \\
51 \\
45 \\
36 \\
69 \\
53 \\
42\end{array}$ & $\begin{array}{r}100 \\
69 \\
38 \\
34 \\
49 \\
28 \\
52 \\
-06 \\
31 \\
52 \\
55 \\
48 \\
65 \\
79 \\
68 \\
79 \\
54 \\
85 \\
73 \\
77 \\
77 \\
72 \\
73 \\
75 \\
78 \\
75 \\
36 \\
28 \\
44 \\
72 \\
54 \\
29 \\
71 \\
72 \\
59 \\
31 \\
66 \\
55 \\
68\end{array}$ & $\begin{array}{r}100 \\
62 \\
53 \\
71 \\
28 \\
28 \\
42 \\
26 \\
55 \\
43 \\
63 \\
33 \\
49 \\
83 \\
71 \\
65 \\
42 \\
86 \\
70 \\
73 \\
66 \\
54 \\
51 \\
69 \\
59 \\
67 \\
31 \\
19 \\
44 \\
51 \\
43 \\
02 \\
62 \\
60 \\
48 \\
30 \\
58 \\
48 \\
36\end{array}$ & $\begin{array}{r}100 \\
79 \\
76 \\
54 \\
50 \\
33 \\
42 \\
50 \\
68 \\
29 \\
43 \\
71 \\
39 \\
32 \\
34 \\
63 \\
38 \\
47 \\
30 \\
28 \\
42 \\
32 \\
46 \\
36 \\
49 \\
37 \\
33 \\
15 \\
32 \\
32 \\
37 \\
48 \\
61 \\
49 \\
48 \\
36 \\
24\end{array}$ & $\begin{array}{r}100 \\
79 \\
47 \\
55 \\
24 \\
22 \\
42 \\
47 \\
26 \\
35 \\
68 \\
28 \\
23 \\
29 \\
48 \\
42 \\
37 \\
28 \\
28 \\
32 \\
30 \\
31 \\
25 \\
54 \\
45 \\
37 \\
18 \\
36 \\
21 \\
25 \\
26 \\
26 \\
22 \\
36 \\
23 \\
19\end{array}$ & $\begin{array}{r}100 \\
51 \\
54 \\
40 \\
29 \\
51 \\
46 \\
13 \\
34 \\
72 \\
40 \\
42 \\
26 \\
80 \\
49 \\
40 \\
45 \\
32 \\
28 \\
49 \\
21 \\
33 \\
58 \\
42 \\
48 \\
31 \\
30 \\
27 \\
33 \\
34 \\
64 \\
27 \\
36 \\
39 \\
22\end{array}$ & $\begin{array}{r}100 \\
79 \\
29 \\
14 \\
72 \\
64 \\
43 \\
57 \\
34 \\
06 \\
42 \\
44 \\
47 \\
35 \\
41 \\
46 \\
33 \\
51 \\
39 \\
60 \\
48 \\
67 \\
56 \\
34 \\
57 \\
46 \\
12 \\
45 \\
43 \\
53 \\
58 \\
45 \\
37 \\
26\end{array}$ & $\begin{array}{r}100 \\
10 \\
28 \\
75 \\
58 \\
52 \\
68 \\
39 \\
23 \\
58 \\
53 \\
51 \\
53 \\
48 \\
52 \\
41 \\
54 \\
57 \\
78 \\
65 \\
67 \\
65 \\
51 \\
67 \\
62 \\
09 \\
58 \\
52 \\
43 \\
58 \\
66 \\
44 \\
45\end{array}$ & $\begin{array}{r}100 \\
24 \\
-04 \\
14 \\
-28 \\
-13 \\
27 \\
-13 \\
02 \\
03 \\
29 \\
02 \\
14 \\
11 \\
03 \\
-11 \\
07 \\
-62 \\
-13 \\
12 \\
05 \\
32 \\
-19 \\
-08 \\
14 \\
06 \\
04 \\
52 \\
46 \\
-30 \\
51 \\
-22\end{array}$ \\
\hline
\end{tabular}




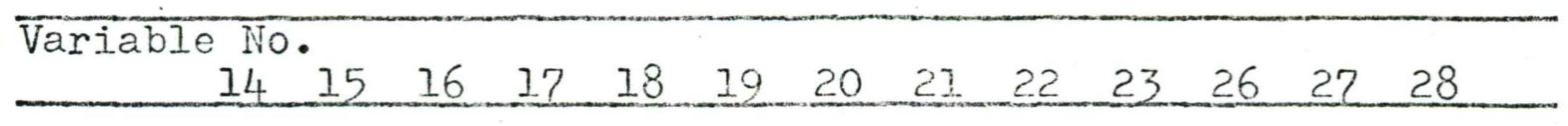

14100

$\begin{array}{lll}15 & 24 & 100\end{array}$

$\begin{array}{llll}16 & 51 & 68 & 100\end{array}$

$\begin{array}{lllll}17 & 38 & 61 & 79 & 100\end{array}$

$\begin{array}{llllll}18 & 25 & 76 & 79 & 74 & 100\end{array}$

$\begin{array}{lllllll}19 & 25 & 49 & 70 & 63 & 77 & 100\end{array}$

$\begin{array}{llllllll}20 & 41 & 35 & 79 & 74 & 78 & 83 & 100\end{array}$

$\begin{array}{llllllll}21 & 24 & 68 & 51 & 35 & 72 & 100\end{array}$

$\begin{array}{lllllllllll}22 & 23 & 50 & 73 & 67 & 77 & 76 & 82 & 60 & 100\end{array}$

$\begin{array}{lllllllllll}23 & 34 & 41 & 82 & 57 & 72 & 87 & 79 & 84 & 100\end{array}$

$\begin{array}{llllllllllll}26 & 38 & 55 & 61 & 54 & 65 & 81 & 80 & 81 & 67 & 78 & 100\end{array}$

$\begin{array}{lllllllllllll}27 & 36 & 51 & 70 & 59 & 75 & 84 & 80 & 82 & 68 & 71 & 82 & 100\end{array}$

$\begin{array}{rrrrrrrrrrrrrr}28 & 21 & 65 & 62 & 50 & 75 & 100 & & 86 & 61 & & 74 & 87 & 100 \\ 29 & 34 & 38 & 48 & 39 & 52 & 71 & 63 & 79 & 61 & 75 & 83 & 75 & 72\end{array}$

$\begin{array}{llllllllllllll}29 & 34 & 38 & 48 & 39 & 52 & 71 & 63 & 79 & 61 & 75 & 83 & 75 & 72\end{array}$

$\begin{array}{llllllllllllll}30 & 14 & 59 & 60 & 51 & 71 & 45 & 43 & 81 & 61 & 49 & 69 & 85 & 80\end{array}$

$\begin{array}{llllllllllll}31 & 23 & 63 & 59 & 41 & 74 & 100 & 91 & 55 & 85 & 89 & 87\end{array}$

$\begin{array}{lllllllllll}32 & 26 & 74 & 69 & 67 & 81 & 82 & 66 & 89 & 93 & 73\end{array}$

$\begin{array}{llllllllllll}33 & 01 & 63 & 61 & 46 & 71 & 100 & 86 & 59 & 85 & 95 & 85\end{array}$

$\begin{array}{rrrrrrrrrrrrrr}35 & 14 & 61 & 44 & 29 & 53 & 46 & 32 & 35 & 46 & 51 & 39 & 28 & 32 \\ 36 & 27 & 51 & 38 & 27 & 39 & 12 & -10 & 12 & 40 & 37 & 28 & 07 & 19\end{array}$

$\begin{array}{llllllllllllll}37 & 50 & 51 & 28 & 10 & 32 & 42 & 4.5 & 144 & 23 & 56 & 55 & 32 & 4.7\end{array}$

$\begin{array}{llllllllllll}38 & 09 & 75 & 52 & 51 & 77 & 100 & 89 & 55 & 75 & 79 & 82\end{array}$

$\begin{array}{llllllllllllll}40 & 49 & 55 & 48 & 45 & 63 & 62 & 63 & 75 & 42 & 50 & 82 & 77 & 69\end{array}$

$\begin{array}{rrrrrrrrrrrrrr}41 & 20 & 13 & -07 & 27 & & 31 & 26 & & 05 & 26 & 57 & 27 & \\ 42 & 44 & 55 & 55 & 41 & 64 & 66 & 70 & 89 & 52 & 59 & 85 & 82 & 78\end{array}$

$\begin{array}{llllllllllllll}43 & 49 & 60 & 57 & 45 & 67 & 52 & 46 & 84 & 55 & 46 & 78 & 80 & 76\end{array}$ $\begin{array}{llllllllllll}44 & 20 & 52 & 62 & 47 & 38 & 65 & 63 & 65 & 63 & 58 & 56\end{array}$

$\begin{array}{llllllllllllll}46 & 57 & 45 & 57 & 29 & 37 & 35 & 16 & 29 & 38 & 53 & 32 & 35 & 22\end{array}$ $\begin{array}{llllllllllll}47 & 47 & 90 & 75 & 69 & 91 & & 82 & 77 & 88 & 88 & 92\end{array}$ $\begin{array}{llllllllllllll}50 & 40 & 56 & 53 & 34 & 51 & 72 & 55 & 89 & 59 & 74 & 71 & 73 & 92 \\ 51 & 08 & 55 & 37 & 45 & 67 & 67 & 59 & 67 & 47 & 54 & 49 & 55 & 76\end{array}$ 


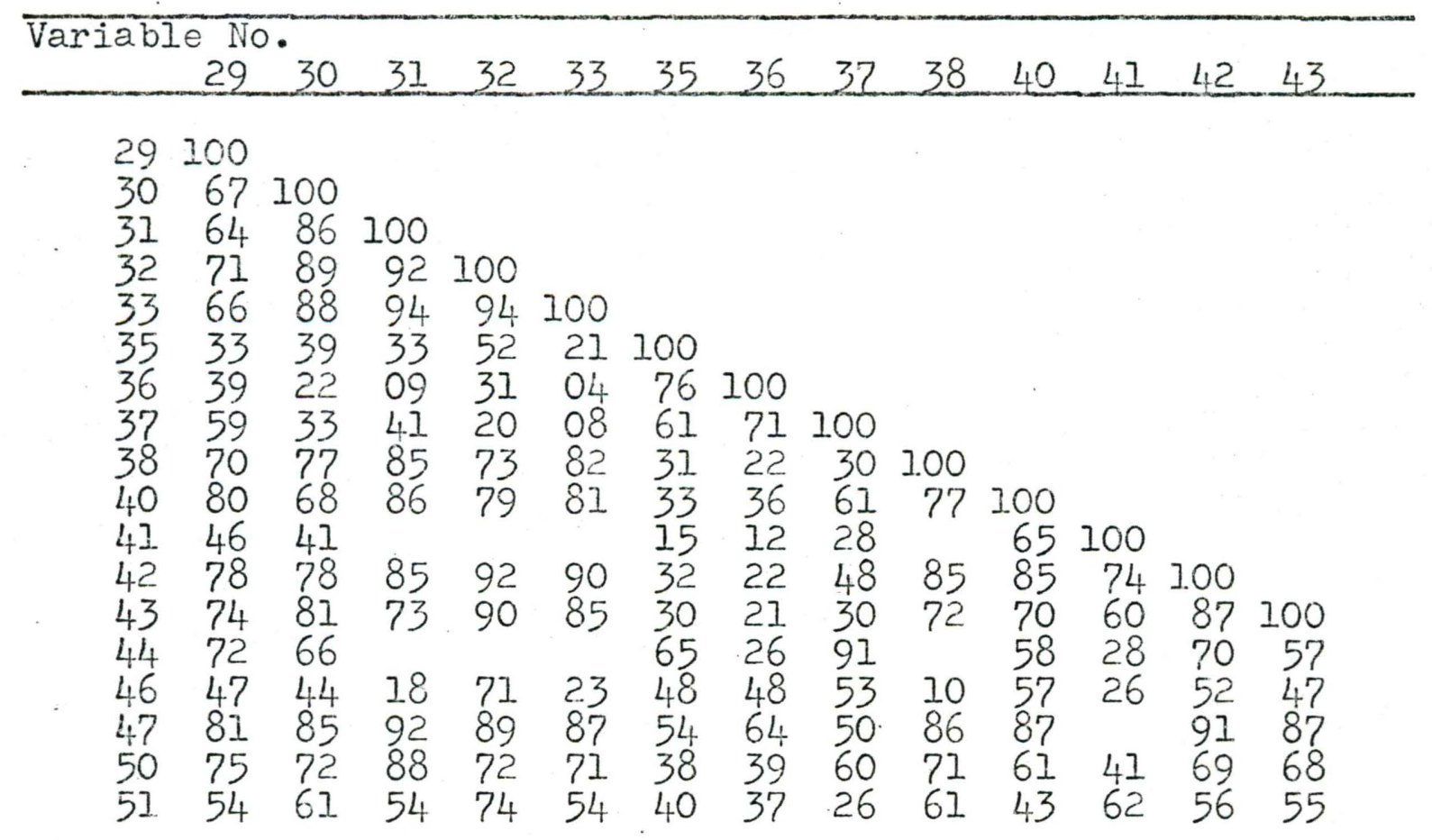




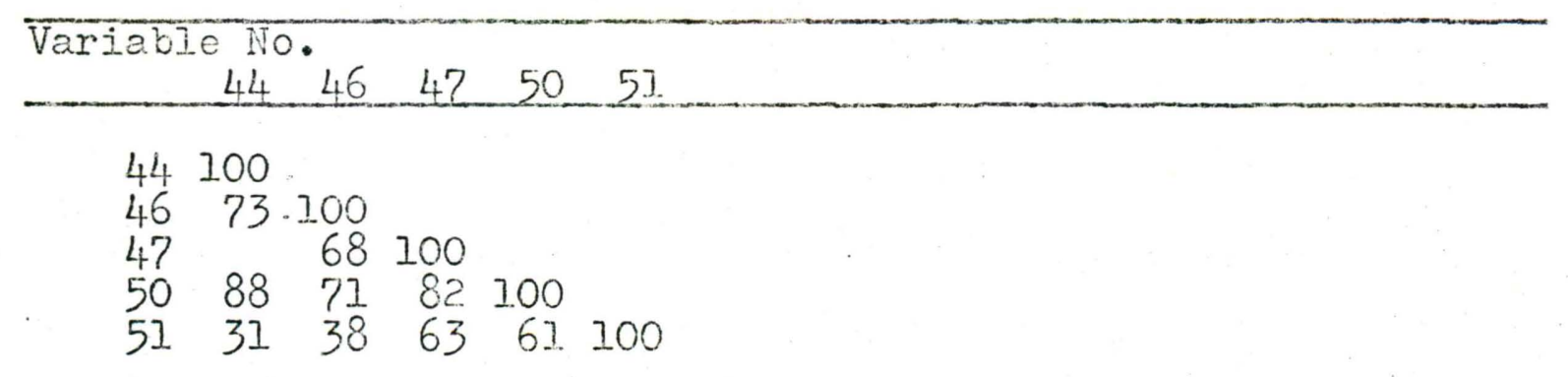

